\title{
MRD-Based Therapeutic Decisions in Genetically Defined Subsets of Adolescents and Young Adult Philadelphia-Negative ALL
}

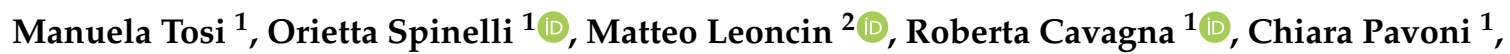 \\ Federico Lussana ${ }^{1}{ }^{1}$, Tamara Intermesoli ${ }^{1}$, Luca Frison ${ }^{2}$, Giulia Perali ${ }^{2}$, Francesca Carobolante ${ }^{2}$, Piera Viero ${ }^{2}$, \\ Cristina Skert ${ }^{2}$, Alessandro Rambaldi ${ }^{1,3}$ and Renato Bassan ${ }^{2, *}$ (i)
}

\section{check for} updates

Citation: Tosi, M.; Spinelli, O.; Leoncin, M.; Cavagna, R.; Pavoni, C.; Lussana, F.; Intermesoli, T.; Frison, L.; Perali, G.; Carobolante, F.; et al. MRD-Based Therapeutic Decisions in Genetically Defined Subsets of Adolescents and Young Adult Philadelphia-Negative ALL. Cancers 2021, 13, 2108. https://doi.org/ 10.3390/cancers13092108

Academic Editor: Andrei Tchirkov

Received: 2 April 2021

Accepted: 22 April 2021

Published: 27 April 2021

Publisher's Note: MDPI stays neutral with regard to jurisdictional claims in published maps and institutional affiliations.

Copyright: (c) 2021 by the authors. Licensee MDPI, Basel, Switzerland. This article is an open access article distributed under the terms and conditions of the Creative Commons Attribution (CC BY) license (https:/ / creativecommons.org/licenses/by/ $4.0 /)$.
1 Hematology Unit, Azienda Socio Sanitaria Territoriale (ASST), Ospedale Papa Giovanni XXIII, 24127 Bergamo, Italy; mtosi@asst-pg23.it (M.T.); ospinelli@asst-pg23.it (O.S.); robertacavagna@outlook.com (R.C.); cpavoni@asst-pg23.it (C.P.); flussana@asst-pg23.it (F.L.); tintermesoli@asst-pg23.it (T.I.); arambaldi@asst-pg23.it (A.R.)

2 Hematology Unit, Azienda Ulss3 Serenissima, Ospedale dell'Angelo, 30174 Venezia-Mestre, Italy; matteo.leoncin@aulss3.veneto.it (M.L.); luca.frison@aulss3.veneto.it (L.F.); giulia.perali@aulss3.veneto.it (G.P.); francesca.carobolante@aulss3.veneto.it (F.C.); piera.viero@aulss3.veneto.it (P.V.); cristina.skert@aulss3.veneto.it (C.S.)

3 Department of Oncology-Hematology, University of Milan, 20122 Milan, Italy

* Correspondence: renato.bassan@aulss3.veneto.it; Tel.: +39-041-965-7362

Simple Summary: In acute lymphoblastic leukemia (ALL), once a complete remission is achieved following induction chemotherapy, the study of submicroscopic minimal residual disease (MRD) represents a highly sensitive tool to assess the efficacy of early chemotherapy courses and predict outcome. Because of the significant therapeutic progress occurred in adolescent and young adult (AYA) ALL, the importance of MRD in this peculiar age setting has grown considerably, to refine individual prognostic scores within different genetic subsets and support specific risk and MRDoriented programs. The evidence coming from the most recent MRD-based studies and the new therapeutic directions for AYA ALL are critically reviewed according to ALL subset and risk category.

Abstract: In many clinical studies published over the past 20 years, adolescents and young adults (AYA) with Philadelphia chromosome negative acute lymphoblastic leukemia (Ph- ALL) were considered as a rather homogeneous clinico-prognostic group of patients suitable to receive intensive pediatric-like regimens with an improved outcome compared with the use of traditional adult ALL protocols. The AYA group was defined in most studies by an age range of $18-40$ years, with some exceptions (up to 45 years). The experience collected in pediatric ALL with the study of post-induction minimal residual disease (MRD) was rapidly duplicated in AYA ALL, making MRD a widely accepted key factor for risk stratification and risk-oriented therapy with or without allogeneic stem cell transplantation and experimental new drugs for patients with MRD detectable after highly intensive chemotherapy. This combined strategy has resulted in long-term survival rates of AYA patients of $60-80 \%$. The present review examines the evidence for MRD-guided therapies in AYA's $\mathrm{Ph}-\mathrm{ALL}$, provides a critical appraisal of current treatment pitfalls and illustrates the ways of achieving further therapeutic improvement according to the massive knowledge recently generated in the field of ALL biology and MRD/risk/subset-specific therapy

Keywords: acute lymphoblastic leukemia; adolescents and young adults; risk stratification; minimal residual disease; risk-oriented therapy

\section{Introduction}

Acute lymphoblastic leukemia (ALL) is the most common type of cancer in children, peaking at 7.6:100.000/year at 1-4 years of age and decreasing in adolescents and young 
adults (AYA), to an average incidence of 1.8 and 0.8 between 15 and 39 years of age [1,2]. Therapeutic progress has been outstanding in childhood ALL over the past decades, now reaching an $80-90 \%$ chance of cure [3,4]. Although therapeutic results are progressively less favorable with the increase of patient age, the case of AYA patients is unique. AYAs have often been treated by adult ALL specialists with adult ALL protocols, a setting in which the favorable prognostic influx of a younger patient age has been consistently recognized [5]. Moreover, AYA patients share several diagnostic and clinical features in common with children and exhibit a higher tolerance to modern highly effective pediatric regimens, which makes them eligible to receive these pediatric-type treatments. The latter concept was explored in several clinical trials that eventually confirmed and provided an explanation for the therapeutic superiority of modern pediatric regimens compared to standard adult protocols in AYA ALL [6].

In ALL, beyond treatment itself that plays by definition a primary prognostic role, among all recognizable risk factors, a key point concerns the course of minimal residual disease (MRD) during the early consolidation phase in patients who respond well and achieve a complete hematologic remission (CR) following induction chemotherapy $[7,8]$. $\mathrm{MRD}$ is a fundamental, independent prognostic parameter that reflects the dynamics of chemo-sensitivity of the residual submicroscopic ALL cell burden to a given chemotherapy program in individual patients, whatever the underlying disease subset, ALL genetics and clinical risk profile. For these reasons, the collection of MRD data has become an essential component of modern treatment strategies for ALL at all ages, first to optimize the definition of risk class and provide an individual prognosis and, second, of equal or even greater importance, to align treatment type and intensity with the MRD-related risk of systemic relapse $[9,10]$.

In the present review, we examine the evidence for the use of MRD analysis in the upfront management of AYA ALL. Because until now MRD-oriented trials were almost exclusively performed in Philadelphia chromosome-negative (Ph-) ALL, we exclude from our survey the subset of Ph+ ALL, which is also significantly less frequent in AYAs compared to older patients. We wish to underline that, once successfully treated, AYA patients, including children, are those who may experience the greatest benefit in terms of future life years and quality of their life. Disclosing the potential for cure or on the contrary the risk of failure through an MRD analysis integrated with other significant risk parameters is therefore of paramount importance in AYAs, to support and optimize risk-related treatment choices and results.

\section{ALL in Adolescents and Young Adult Patients}

Quite frequently, in the past, AYA patients with Ph- ALL have been included in adult ALL trials enrolling patients within a broad age range (from 15-18 to 55-65 years). While it may be difficult to extrapolate exact AYA data and results from these trials, they remain an important source of information regarding AYA ALL since the median patient age in most adult ALL studies is around 35-40 years and therefore some 50\% of study patients fall within the AYA category. Instead, selected age ranges were rather heterogeneous in dedicated AYA trials, variably extending up to between 25 and 45 years, which makes it similarly difficult, as well as somewhat artificial, to set exact and universal age boundaries for AYA ALL. In addition, in some large pediatric trials, the upper patient age was extended to include all teens and younger adults, up to 25-30 years [11-13] or even 45 years [14], sometimes without clearly separating outcome results of children from AYAs [12,13]. In all these studies, the diagnostic characteristics of AYA ALL, genetics in first place, were intermediate between those observed in children and older adults. Overall, once the challenge of improving the outcome of AYA patients was correctly perceived and the first innovative trials demonstrated the advantages of using modern pediatric rather than historical adult programs, the new approach was rapidly adopted by virtually all cooperative adult ALL Study Groups worldwide [9,15-17] and is highly recommended at present. All these topics are considered in the following sections. 


\subsection{AYA Patient Identification: Age Ranges}

While AYAs can represent roughly one half of all study patients in adult ALL trials (median patient age 35-40 years), there is no formal consensus for the patient age range in AYA-dedicated trials, this ranging from 15-18 to 35-45 years. Here, we refer for simplicity to AYA ALL as 18-40 years of age, with exceptions that are reported. It is worth recognizing that even patients aged $40-45$ to $50-55$ years were rather successfully treated with the same pediatric-based regimens used in children and AYAs.

\subsection{Ph-ALL: Diagnostic Subsets Defined by Immunophenotype and Cytogenetics/Genetics in $A Y A s$}

Whereas the incidence of the two main immunophenotypic ALL subsets does not vary significantly across age groups, with B-cell precursor (BCP) ALL representing the majority of new cases and T-ALL no more than $20-25 \%$, the distribution of different genetic subsets shows a definite age-related pattern, with a lower incidence of the favorable ones in AYAs compared to children (Table 1).

Table 1. Summary table comparing the age-related incidence (percent of all evaluable cases) of main genetic/cytogenetic abnormalities in BCP ALL (data adapted from Roberts KG et al. [18]).

\begin{tabular}{|c|c|c|c|c|c|}
\hline ALL Subset & $\begin{array}{l}\text { Prognostic } \\
\text { Category }\end{array}$ & $\begin{array}{c}\text { Genetic/Cytogenetic } \\
\text { Abnormality }\end{array}$ & $\begin{array}{l}\text { Children } \\
\text { (<15 Years) }\end{array}$ & $\begin{array}{c}\text { AYA } \\
\text { (15-40 Years) }\end{array}$ & $\begin{array}{l}\text { Older Adults } \\
\text { (>40 Years) }\end{array}$ \\
\hline \multirow{5}{*}{$\mathrm{Ph}-$} & Favorable & $\begin{array}{l}\text { High hyperdiploidy } \\
\text { t(12;21)/ETV6-RUNX1 }\end{array}$ & $\begin{array}{c}20-25 \% \\
25 \%\end{array}$ & $\begin{array}{c}5 \% \\
<5 \%\end{array}$ & $\begin{array}{l}<5 \% \\
1 \%\end{array}$ \\
\hline & \multirow[t]{2}{*}{ Intermediate } & $\begin{array}{l}\text { Normal Karyotype } \\
\text { t(1;19)/TCF3-PBX1 }\end{array}$ & $\begin{array}{l}10 \% \\
5 \%\end{array}$ & $\begin{array}{l}- \\
<5 \%\end{array}$ & $\begin{array}{c}- \\
1 \%\end{array}$ \\
\hline & & Low hypodiploidy, & $1 \%$ & $5 \%$ & $>10 \%$ \\
\hline & \multirow{2}{*}{ Unfavorable } & $\mathrm{t}(\mathrm{v} ; 11) / \mathrm{KMT} 2 \mathrm{~A}+$ & $6 \%$ & $4 \%$ & $15 \%$ \\
\hline & & $\mathrm{Ph}$-like & $10-15 \%$ & $25-30 \%$ & $20 \%$ \\
\hline $\mathrm{Ph}+$ & Unfavorable * & $\mathrm{t}(9 ; 22) / \mathrm{BCR}-\mathrm{ABL} 1$ & $2 \%$ & $6 \%$ & $25 \%$ \\
\hline
\end{tabular}

* Turning standard/intermediate-risk with the introduction of TKI-based therapies.

The majority of chromosomal and genetic alterations detectable in AYA ALL belong to the intermediate risk (including the normal karyotype subset) or intermediate-high risk categories, or even high-risk categories [18-21], such as the Ph-like ALL variant, which is a prognostically adverse entity. Genetically, Ph-like ALL resembles in many ways Ph+ ALL but lacks its diagnostic hallmark (Ph chromosome and BCR-ABL1 gene rearrangement) and carries instead other genetic aberrancies (frequently CLRF2+ and abnormal tyrosine kinase and JAK/STAT pathway activation). Of note, independent European and North American studies in large patient series disclosed an incidence of $25-30 \%$ for Ph-like ALL in the 20-39 years range, which was higher than that observed in younger and older patients, respectively [22].

In addition, copy number alterations (CNA), i.e., gene deletion or inactivation affecting several molecular pathways regulating cell proliferation and apoptosis response, may occur and bear prognostic relevance. Single or multiple CNA were detected in association with major genetic abnormalities. This exerted a pejorative prognostic effect, particularly with IKZF1 (Ikaros) and CDKN2A/2B deletions and others [23], such as in IKZF1plus BCP ALL, in which IKZF1 deletions co-occurred with CDKN2A/2B, PAX5 or PAR1 deletions conferring the worst outcome [24]. The analysis of CNA was recently incorporated in some of the most advanced prospective risk models (see Section 2.3).

Due to its relative rarity, the age distribution of genetic/cytogenetic abnormalities and their prognostic significance are much less well known in AYA T-ALL. By inference with data collected in T-ALL in general, a novel four-gene prognostic classifier may reflect poor risk genetics (unmutated NOTCH1/FBXW7 and/or RAS and PTEN abnormalities) [25,26], whereas for many other genetic abnormalities detectable in T-ALL no firm prognostic significance has been established. Approximately $15 \%$ of T-ALL cases display an early-thymic 
precursor (ETP) immunophenotype with absent/weak CD5 expression, cross-lineage expression of immature myeloid markers and a typical, dysregulated gene expression profile (JAK/STAT, FLT-3, BCL-2, etc.). ETP ALL is considered a potential high-risk ALL entity [27-29].

\subsection{Treatment: Traditional Adult vs. Modern Pediatric Regimens}

Although it is not the main focus of the present review, the importance of an optimal treatment regimen for AYA ALL must be correctly understood. Some excellent reviews have recently been dedicated to this topic $[6,16,17]$. A summary of the evidence collected in comparative and non-comparative trials assessing the feasibility and efficacy of "pediatrictype" chemotherapy in AYA and adult ALL is presented in Table 2. The trials herein considered were selected on the basis of patient number (minimum of 50) and timing for data analysis and outcome reporting (minimum of 3 years) and are presented according to increasing patient age groups from younger AYA only to adult trials including AYA patients.

Table 2. Key findings from selected trials of pediatric-based regimens for AYA and adult Ph- ALL. The projected overall survival (OS), relapse-free survival (RFS) and event-free survival(EFS) at $\geq 3$ years are shown. Data are ordered according to increasing patient age groups.

\begin{tabular}{|c|c|c|c|c|c|c|}
\hline Age Groups and Trials (Ref.) & $\begin{array}{c}\text { Patient Age (Years), } \\
\text { Median (Range) }\end{array}$ & $\begin{array}{l}\text { No. of } \\
\text { Patients }\end{array}$ & $\begin{array}{l}\text { Outcome } \\
\text { Estimates } \\
\text { (y, Years) }\end{array}$ & OS (\%) & RFS (\%) & EFS (\%) \\
\hline \multicolumn{7}{|c|}{ Maximum age $\leq 25$ years } \\
\hline FRALLE-93 ${ }^{1}$ [30] & $15.9(15-20)$ & 77 & $5-y$ & 78 & 72 & 67 \\
\hline CCG $1882 / 191^{1}[31]$ & $16(16-20)$ & 197 & $7-y$ & 67 & - & 63 \\
\hline JALSG ALL202-U [32] & $19(15-24)$ & 139 & $5-y$ & 73 & 67 & - \\
\hline CCG $19,61^{1}[33]$ & $(16-21)$ & 262 & $5-y$ & 78 & - & 72 \\
\hline MRC UKALL 2003 [11] & $(16-24)$ & 229 & $5-y$ & 76 & - & 72 \\
\hline \multicolumn{7}{|c|}{ Maximum age $\leq 40$ years } \\
\hline PETHEMA ALL-96 [34] & $20(15-30)$ & $\overline{81}$ & $6-y$ & 69 & - & 61 \\
\hline PETHEMA ALLRE08 [35] & $20(15-30)$ & 66 & $5-y$ & 74 & - & - \\
\hline MDACC (augmented BFM) * [36] & $22(13-39)$ & 106 & $5-\mathrm{y}$ & 60 & - & - \\
\hline CALGB 10,403 [37] & $24(17-39)$ & 295 & $3-y$ & 73 & 66 & 59 \\
\hline FRALLE 2000-BT [38] & $(15-29)$ & 89 & $5-y$ & 66 & - & 61 \\
\hline GMALL 07/03 [39] & $(15-35)$ & 887 & $5-y$ & 65 & 61 & - \\
\hline GIMEMA LAL1308 [40] & $(18-35)$ & 76 & $4-y$ & 60 & 60 & - \\
\hline HOVON-100 ${ }^{1}[41]$ & $(18-40)$ & 159 & $5-y$ & $60-56^{2}$ & 58 & $61-64^{2}$ \\
\hline \multicolumn{7}{|c|}{ Maximum age $\leq 55$ years } \\
\hline NOPHO ALL2008 [14] & $26(18-45)$ & 221 & $5-y$ & 78 & - & - \\
\hline DFCI 01-175 ${ }^{1}$ [42] & $28(18-50)$ & 92 & $4-y$ & 67 & 69 & 69 \\
\hline DFCI 06-254 ${ }^{1}[43]$ & $32(18-50)$ & 89 & $3-y$ & 75 & 73 & 73 \\
\hline GMALL 07/03 [44] & $35(15-55)$ & 1226 & $3-y$ & $60-67^{3}$ & - & - \\
\hline \multicolumn{7}{|c|}{ Maximum age $>55$ years } \\
\hline RALL 2009 [45] & $30(15-60)$ & 250 & $4-y$ & 66 & 69 & - \\
\hline GRAALL-2003 [46] & $31(15-60)$ & 225 & $3.5-y$ & 60 & 59 & 55 \\
\hline GRAALL-2005 [47] & $36(18-59)$ & 787 & $5-y$ & 59 & - & 52 \\
\hline Toronto (DFCI 91-01) [48] & $37(18-60)$ & 85 & $5-y$ & 63 & 71 & - \\
\hline PETHEMA ALL-HR-11 [49] & $40(15-60)$ & 348 & $5-y$ & 49 & - & 40 \\
\hline JALSG ALL 202-O [50] & $40(24-65)$ & 115 & $5-y$ & 64 & 58 & - \\
\hline NILG $10 / 07^{4}[51]$ & $41(18-65)$ & 161 & $5-y$ & 52 & 53 & 46 \\
\hline
\end{tabular}

* Outcome not improved in comparison with historical, traditional adult-type treatment; outcome was comparatively improved in all other studies without an asterisk (figures not reported, available in references); ${ }^{1}$ including a proportion of patients with Ph+ ALL (exact figures in study in trial reports); ${ }^{2}$ by randomization arm $(+/-$ Clofarabine $){ }^{3}$ referred to two different Pegylated-Asparaginase treatment cohorts; 4 outcome estimates for 135 patients 18-55 years: 5-year OS 60\%, RFS 56\%, EFS 52\%. Abbreviations: CALGB, Cancer and Leukemia Group B; CCG, Children's Cancer Group; DFCI, Dana Farber Cancer Institute; GIMEMA, Gruppo Italiano Malattie Ematologiche dell'Adulto; GMALL, German Multicenter Study Group for Adult ALL; GRAALL, Group for Research on Adult ALL; HOVON, Hemato-Oncology Foundation for Adults in the Netherlands; JALSG, Japan Adult Leukemia Study Group; MDACC, M.D. Anderson Cancer Center; NILG, Northern Italy Leukemia Study Group; NOPHO, Nordic Society of Pediatric Hematology and Oncology; PETHEMA, Programa Español de Tratamientos en Hematología; RALL, Russian ALL Study Group; UKALL, United Kingdom ALL Study Group. 
Overall, the available information generated by the use of "pediatric" treatments in AYA ALL can be summarized as follows:

1. Intensive chemotherapy regimens inspired to modern pediatric schedules and treatment principles are superior to historical adult-type programs, as demonstrated with very few exceptions by comparative analyses among successive Phase 2 trials and many large non-comparative trials $[6,16,17]$. Whenever available, retrospective comparisons with historical datasets (not shown in the table and available in study references) confirm an average improvement of outcome measures of $15-25 \%$.

2. In these modern AYA or AYA-containing adult ALL studies, the projected survival rates at 5 years (range 3-7 years), assuming "cure" for most patients who remain disease-free at $\geq 5$ years, is $50 \%$ and greater (overall survival, OS), with age-related variations and OS rates of $60-70 \%$ and occasionally higher in younger age groups.

3. Unlike OS, which reflects the cumulative survival effect of both first line and salvage therapies, relapse-free and event-free survival (RFS and EFS) depict the curative potential of upfront therapy only, in CR patients and all study patients, respectively. These figures range 55-70\% (RFS) and 40-74\% (EFS), once again with significantly better results in younger age groups.

4. The overall chemotherapy intensity is increased in pediatric-based regimens, with regard to vincristine, corticosteroids, antimetabolites (cytarabine, methotrexate and 6-mercaptopurine), L-asparaginase and, more recently, Pegylated-asparaginase (PegASP). Consequently, drug-related toxicity may be higher, requiring higher clinical skills for the management and prevention of toxic side effects.

5. The improved pediatric-like protocol may consist of an unmodified or modified pediatric schedule, in the latter case adapting some treatment elements to an increasing patient age with attending risks of treatment toxicity. The issue of Peg-ASP dosing and toxicity is highly critical in patients at older age [52,53].

6. Contrary to younger patients, it appears difficult to demonstrate an advantage by pediatric-type regimens in patients older than 55 years [44,47,51]. Non-AYA patients become progressively less tolerant to intensive treatment and display a higher incidence and severity of toxic side effects.

7. The patients who achieve CR, namely about $90 \%$ of all patients ( $\geq 95 \%$ in younger age groups), are usually risk-stratified to assess the individual risk class and decide about the application of risk-specific treatments that range, for high-risk (HR) patients, from chemotherapy intensification to allogeneic hematopoietic cell transplantation (HCT) and/or experimental new agents. Most patients at standard-risk (SR) or intermediaterisk can achieve cure with a full chemotherapy regimen including maintenance as standard of care, without HCT, this lowering the incidence of non-lethal and lethal toxicities (10-15\% average mortality from HCT).

8. In the risk stratification process, by analogy with pediatric trials, the analysis of post-induction MRD is crucial since it has been demonstrated to be the most powerful predictive factor for marrow relapse in multivariable analysis from several studies [7-10]. Therefore, MRD is currently used together with other risk factors for the definition of risk groups and individual risk profiles.

With regard to MRD-based risk stratification, the choice of MRD study method and time-point(s) as well as the layout of the final risk model have been quite variable across trials. In some studies, MRD was used alone or in combination with a minimal set of variables (i.e., very high-risk genetics such as KMT2A rearrangements), while in others it was part of complex risk models involving multiple risk factors. These differences are reported in a review article on the risk stratification criteria adopted by 11 European adult ALL Study Groups to orientate an allogeneic HCT decision (Table 3) [54]. This survey documents a consistent use of MRD (11/11, 100\%) together with the frequent addition of selected adverse genetic/cytogenetic abnormalities $(8 / 11,73 \%)$ to support a diagnosis of HR ALL with an indication for allogeneic HCT. 
Table 3. Summary of risk factors considered by 11 European adult ALL study groups for risk stratification orientating the choice of an allogeneic HCT in first CHR in Ph- ALL (all studies including AYA patients), adapted from [54]. For MRD levels defining MRD POS status.

\begin{tabular}{ccccc}
\hline Study Group & MRD & Genetics & WBC & Miscellaneous \\
\hline RALL & + & $\begin{array}{c}\text { KMT2A+ } \\
\text { t(1;19) }\end{array}$ & - & Age $>30$ \\
\hline GMALL & + & KMT2A & $>30(\mathrm{~B})$ & $\begin{array}{c}\text { Late CR, proB, } \\
\text { early } / \text { mature-T }\end{array}$ \\
\hline HOVON & + & adverse & $>30(\mathrm{~B}),>100(\mathrm{~T})$ & Late CR \\
\hline PALG & + & KMT2A+ & $>30(\mathrm{~B}),>100(\mathrm{~T})$ & CNS+ \\
\hline GIMEMA & + & $\begin{array}{c}\text { Abn11q, } \\
\text { hypodiploid }\end{array}$ & $>100$ & $\begin{array}{c}\text { Late CR, D15 BM } \\
\text { blasts }>25 \%\end{array}$ \\
\hline UKALL & + & adverse & High counts & Early /mature-T \\
\hline SVALL & + & $\begin{array}{c}\text { KMT2A+, } \\
\text { hypodiploidy }\end{array}$ & - & EOI BM blasts $>5 \%$ \\
\hline CELL & + & - & - & - \\
\hline PETHEMA & + & - & - & - \\
\hline GRAALL & + & - & - & - \\
\hline
\end{tabular}

Complete list of adverse genetics/cytogenetics available in original study references. Abbreviations: WBC, white blood cells $\left(\times 10^{9} / \mathrm{L}\right)$; BM, bone marrow; CNS, central nervous system; D, day; EOI, end of induction; CELL, Czech Leukemia Study Group; FALL, Finnish ALL Study Group; GIMEMA, Gruppo Italiano Malattie Ematologiche dell'Adulto; GMALL, German Multicenter Study Group for Adult ALL; GRAALL, Group for Research on Adult ALL; HOVON, Hemato-Oncology Foundation for Adults in the Netherlands; PALG, Polish Adult Leukemia Group; PETHEMA, Programa Español de Tratamientos en Hematología; RALL, Russian ALL Study Group; SVALL, Swedish Adult ALL Study Group; UKALL, United Kingdom ALL Study Group.

The increasing precision and complexity of MRD-based risk stratifications is further illustrated in another risk model from an ongoing International pediatric and AYA project (age range 1-45 years), i.e., the ALLTogether study, in which the very large enrolment basis and thorough diagnostic work-up allow very accurately refining the patient risk class for risk-oriented treatments (Figure 1) [55].

Quite interestingly, in this study conceived by a childhood ALL Consortium, the diagnosis of T-ALL and a patient age $>16$ years qualified for an intermediate-high risk classification even with undetectable post-induction MRD and/or lack of other risk factors, to reflect the long-lasting notion of a worse outcome expected for patients aged $\geq 15$ years in the pediatric setting. Unlike this, age or T-ALL diagnosis do not represent a clear risk classifier in most adult/AYA trials, although some differences are reported in favor of teens and AYA < 5 years (Table 3). The ALLTogether trial design highlights the place of a mixed $\mathrm{MRD} /$ genetic prospective risk classification that influences the chemotherapy intensity from SR to HR groups and guides the application of an allogeneic HCT or the randomized evaluation of additional risk/subset-specific therapeutic elements in intermediate/highrisk patients (CAR-T cells, tyrosine kinase inhibitors and immunotherapy), many of whom express high MRD levels, as well as treatment de-escalation in SR patients.

Combined risk stratification systems merging MRD and genetics were previously assessed in both childhood and adult ALL, enhancing the accuracy of risk stratification $[23,26,56,57]$. The UKALL-14 adult study introduced a novel prognostic index (PI $\left.\mathrm{UKALL}_{\mathrm{U}}\right)$ integrating the WBC count and patient age as continuous variables with cytogenetics/genetics and two post-induction MRD time-points. The PIUKALL prognostic classification was a powerful predictor of outcome following chemotherapy and HCT in SR and HR patients, respectively [57]. The $\mathrm{PI}_{\mathrm{UKALL}}$ was successfully tested in a very large retrospective COG series of more than 21,000 children and adolescents [58]. In the era of precision medicine, risk assessment is an evolving process that depends equally on the optimization of MRD 
analysis and its interaction with ALL biology. MRD detection can be performed by flow cytometry or by a molecular approach.

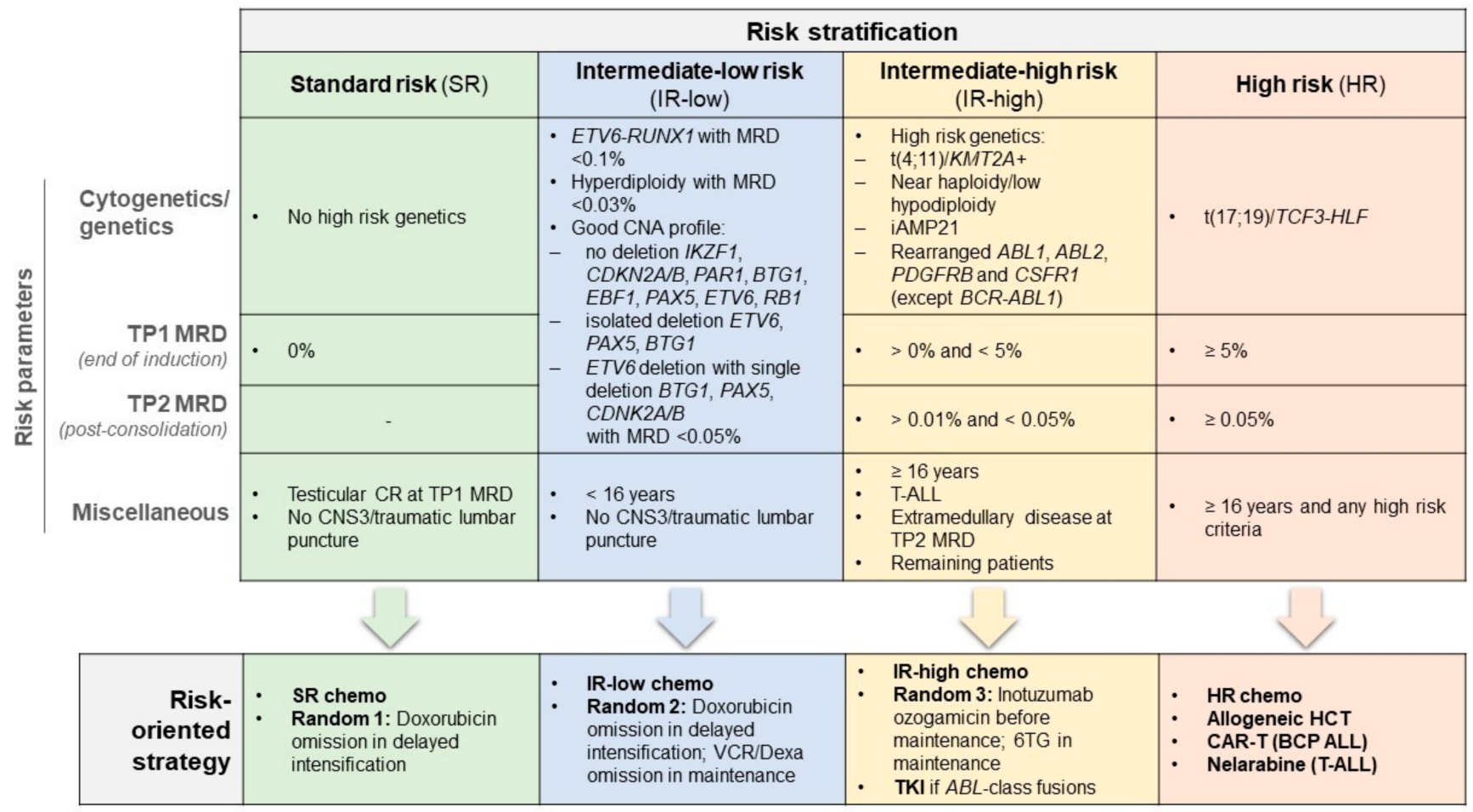

Figure 1. The ALLTogether MRD-based, mixed risk stratification system for risk-oriented therapy in patients with PhALL 1-45 years. The master trial consisted of chemotherapy (chemo) of increasing intensity for SR, IR and HR patients, respectively, along with other risk-specific randomized or non-randomized interventions as indicated. TKI denotes tyrosine kinase inhibitor (imatinib) for cases with ABL-class fusions and CAR-T and BCP denote chimeric antigen receptor T-cell therapy and B-cell precursor ALL, respectively.

\section{Methods of MRD Assessment}

\subsection{Multiparameter Flow Cytometry}

Multiparameter flow cytometry (MFC) is based on a panel of monoclonal antibodies that bind specific cell surface markers useful for distinguishing normal cells from leukemic cells, identifying the leukemia-associated aberrant immunophenotype (LAIP). This method was standardized and constantly refined by the EuroFlow Working Group within the ESHLO Consortium (European Scientific Foundation of Laboratory Hemato-Oncology) which also includes the EuroClonality and EuroMRD European laboratory Groups working on different aspects of leukemia and lymphoma characterization and monitoring [59]. Flow cytometry is faster than the molecular approach but less sensitive (sensitivity of $10^{-4}$, i.e., the ability to detect one leukemic cell among 10,000 normal cells, or $0.01 \%$ ). More recent studies using highly sophisticated eight-color MFC reported an increased sensitivity for MRD detection in B-precursor ALL, up to between $10^{-5}$ and $10^{-6}$ [60].

\subsection{PCR for Fusion Genes and Transcripts}

One third of ALL patients present chromosomal translocation-derived fusion genes, including BCR-ABL1, TCF-PBX1, KMT2A-AFF1 or KMT2A and other partner genes and ETV6-RUNX1 [61]. These chromosomal abnormalities are highly stable over time, therefore are good markers for MRD detection during and monitoring. The MRD quantification is obtained by qRT-PCR (quantitative Reverse Transcription Polymerase Chain Reaction) that compares fusion gene levels detected in a follow-up sample to a standard curve of plasmid containing chimeric-transcript at fixed concentrations [62]. 


\subsection{PCR for Ig and TCR Gene Rearrangements}

If the patients have been tested negative for chromosomal translocation at diagnosis, the molecular gold standard for MRD monitoring is the amplification of T-cell Receptor (TcR) and Immunoglobulin (Ig) gene rearrangements by Real Time quantitative PCR (RQ-PCR). Unlike the chimeric transcript, Ig/TcR are not directly involved in leukemia pathogenesis, but they mirror physiological events that occur during the ontogenesis of $B$ and $\mathrm{T}$ lymphocytes. During lymphocyte differentiation, random insertions/deletions of nucleotides at the junctional sites of $\mathrm{V}$ (Variable)-D (Diversity)-J (Junctional) gene segments result in a diversity of antigen receptor; in the case of neoplastic evolution, all the tumor cells will express the same receptor sequence. Therefore, these insertions/deletions are specific to each patient and represent a fingerprint of leukemia. This approach, according to BIOMED-2 protocol [63], includes the identification at diagnosis of V-D-J regions of Ig and $\mathrm{TcR}$ gene rearrangements by PCR followed by heteroduplex analysis to distinguish between polyclonal and clonal, leukemia specific rearrangements. Nucleotide sequences of the identified clonal rearrangements are obtained by Sanger method. Allele Specific Oligonucleotides (ASO primer) (Figure 2) are then designed on these leukemia-specific sequences and used in combination with family-specific primers and fluorescent probes to identify and quantify leukemia cells by Quantitative PCR (ASO-qPCR). The fluorescence emission detected by the instrument in a sample is directly proportional to the amount of target DNA present.

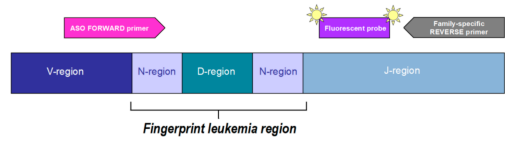

Figure 2. Leukemia specific assay design. An allele-specific oligonucleotide (ASO) primer is designed on the N-region between the V/D or D/J gene junction and used in combination with a familyspecific primer and fluorescent probe. The fluorescence emission detected by the instrument is directly proportional to the amount of target DNA in the sample.

Leukemia quantification in a follow-up sample is derived by comparing the measured fluorescence to serial dilutions of diagnostic material in a pool of mononuclear cells derived from eight healthy donors (standard curve). The MRD result is expressed as the logarithmic reduction compared to diagnosis. To ensure the monitoring of possible multiple leukemia clones, at least two ASO primers should be developed for each patient with a desirable sensitivity of $10^{-4}$ or $10^{-5}$ (i.e., the ability to detect one leukemic cell among 10,000 or 100,000 normal cells, which is $0.01 \%$ and $0.001 \%$, respectively). This method has been developed and standardized by the EuroMRD/EuroClonality Consortium that, during the last 20 years, established precise rules to define both sensitivity of the assay and positivity or negativity of follow-up samples [64]. However, this method has some limitations including time consuming and complex procedures that only specialized laboratories can properly perform. It also requires a good quantity of diagnostic material to be used for standard curve in each follow-up evaluation. In addition, about $5-10 \%$ of patients do not have a leukemia specific probe either because no Ig/TCR rearrangements are detected at diagnosis or because the unique VDJ portion is very short or the designed ASO primer is not sufficiently specific and sensitive.

\subsection{Next Generation Sequencing}

Next-generation sequencing (NGS) is a new method of high-throughput DNA sequencing allowing to overcome some limits of the standard molecular approach. The EuroClonality-NGS working group developed an amplicon-based protocol for Ig/TcR marker identification in ALL. This assay employs a two-step PCR: in the first step, the most common Ig/TcR gene rearrangements are amplified in multiplex reactions with family specific primers (eight reactions), while, in the second step, short forward and reverse sequences (adaptors) are added to uniquely identify single patients and to allow the subse- 
quent reaction phases. Then, a pool of amplification PCR products is created and sequenced by the Illumina or Ion Torrent platform [65-67]. An alternative, capture-based approach has also been described [68,69]. In this method gene rearrangements are not amplified by PCR but hybridized with probes that recognize all V, D and J of all known Ig/TCR regions, including IG Lambda and TcR Alpha that are usually difficult to amplify. This approach can also detect rarely used $\mathrm{V} / \mathrm{D} / \mathrm{J}$ portion for which no primers have been designed in PCR-based methods. Sequences generated by NGS approaches can be analyzed to identify leukemia specific markers by bioinformatics tools, including the ARResT/Interrogate web tool [70] (created by Euroclonality-NGS Consortium) and Vidijil (free tool) [71].

NGS-based clonal identification is routinely used in most MRD reference laboratories because it allows a faster clonal marker identification starting from a small quantity of diagnostic material. It also increases the ability to discriminate rearrangements difficult to resolve by Sanger sequencing. NGS has been reported to be successful also in MRD monitoring [72] and has been described to be at least as sensitive as standard RQ-PCR and to provide MRD quantification without the need of diagnostic material in each assay (standard curve). Furthermore, it allows the certain discrimination between residual leukemia cells and normal lymphocytes that can have similar but not identical rearrangements. However, this approach is still lacking standardization within collaborative groups to be properly applied in treatment protocols. The EuroMRD-NGS group is working on this aspect also introducing an internal quantification reference to allow comparability of results in different MRD laboratories. Furthermore, the available NGS assays for MRD are more expensive and the time to result is longer than ASO-Q-PCR when applied on a routine basis in reference laboratories working on a high number of samples within clinical trial.

\subsection{Digital Droplet PCR}

A promising, effective, low cost, new third-generation PCR for absolute MRD quantification is named digital droplet PCR (ddPCR) [73]. This technique can be applied in leukemia cases in which diagnostic material was sufficient to identify clonal rearrangements but not for preparation of standard curve for MRD quantification, thus limiting the possibility of patients monitoring over time. The analysis is performed by partitioning the follow-up sample amplification into many independent PCR, by inclusion of reagents (ASO fluorescent assay) and DNA into small droplets created by emulsion. The partitioning is a random event following the Poisson distribution. Therefore, with the production of high number of droplets, there is the probability to have either zero or a single molecule of target rearrangements. After amplification, there will be fluorescent droplets (i.e., with PCR product inside) or no fluorescence. The analysis software for the ddPCR will count the number of fluorescent events and will express the result as number of copies of template per microliter of reaction (copies $/ \mu \mathrm{L}$ ), taking into account the final volume of reaction. This will result in an absolute MRD value.

\section{MRD in AYA Ph - ALL}

\subsection{MRD Study Results for Risk Stratification}

MRD study results from representative clinical trials in AYA patients or AYA plus adults when the two groups were treated together are shown in Table 4. Depending on the response definition adopted by each study, MRD cut-off values separating SR from HR patients in a risk-oriented studies ranged from totally negative using highly sensitive molecular probes to $<10^{-3}(<0.1 \%)$, whereas MRD detection timepoints were set from as early as Day 21-24/EOI (end of induction) to treatment Weeks 16-22. The MRD-based risk stratification was quite often unrelated to the initial risk profile (SR or HR) and motivated the choice of an allogeneic HCT in case of MRD persistence. In some of these trials, however, the MRD analysis was available for a limited proportion of patients, which is one half or less of all CR patients, and/or was not clearly or not always meant to guide a risk-oriented approach with $\mathrm{HCT}$, left to the discretion of treating physicians or indicated for very high-risk conditions such as $t(4 ; 11)+A L L$, etc. Despite these discrepancies that 
may affect to some extent trial result interpretation and inter-trial comparability, MRD was universally recognized as a major determinant of outcome supporting risk-oriented treatment decisions.

Table 4. $\mathrm{MRD}_{\text {pos }}$-based results (risk stratification, risk-oriented therapy and clinical outcome) in AYA and adult PhALL trials.

\begin{tabular}{|c|c|c|c|c|c|c|}
\hline \multirow{2}{*}{$\begin{array}{l}\text { Trial/Study } \\
\text { (Ref.) }\end{array}$} & \multirow{2}{*}{$\begin{array}{l}\text { Patient Age } \\
\text { (Years), Median } \\
\text { (Range) }\end{array}$} & \multicolumn{2}{|c|}{ MRD Analysis } & \multicolumn{2}{|c|}{ Favorable MRD Response } & \multirow{2}{*}{$\begin{array}{c}\text { Comparative Outcomes: } \\
\text { Favorable MRD Cut-Offs } \\
\text { Vs. Not }\end{array}$} \\
\hline & & $\begin{array}{c}\text { Evaluable/CR, } \\
\text { No. (\%) }\end{array}$ & Method $^{1}$ & Cut-Off ${ }^{2}$ & No. $(\%)$ & \\
\hline \multicolumn{7}{|c|}{ AYA only (maximum age 40 years) } \\
\hline $\begin{array}{l}\text { MRC- } \\
\text { UKALL2003 } \\
{[11]}\end{array}$ & NR (16-24) & $223 / 229(97)$ & Mol & $\begin{array}{l}\text { Negative } /<0.01 \% \\
\mathrm{~d} 29, \text { negative at } \\
\text { EOC }\end{array}$ & $54(24)$ & $\begin{array}{l}\text { 5-y EFS 93\% vs. } 63-71 \% \\
\qquad(p=0.0001)^{3}\end{array}$ \\
\hline $\begin{array}{l}\text { PETHEMA } \\
\text { ALL08 [35] }\end{array}$ & $20(15-30)$ & $61 / 68(90)$ & MFC & $\begin{array}{c}<0.1 \% \text { w5-6, } \\
<0.05 \% \text { w19-20 }\end{array}$ & $48(77)$ & NR \\
\hline $\begin{array}{c}\text { GIMEMA } \\
\text { LAL1308 [39] }\end{array}$ & NR (18-35) & $\begin{array}{l}64 / 68(94) / \\
66 / 68(97) \\
49 / 68(72) / \\
50 / 68(73)\end{array}$ & $\begin{array}{l}\text { MFC } \\
\text { Mol }\end{array}$ & $<0.1 \%$ d33/78 & $\begin{array}{l}37(58) / 54(82) \\
28(57) / 38(76)\end{array}$ & $\begin{array}{l}\text { 4-y OS by d33 MRD 67-75\% } \\
\text { vs. } 27-41 \%(p=0.002) 4 \\
4 \text {-y RFS by d33 MRD 67-73\% } \\
\text { vs. } 27-43 \%(p \leq 0.025){ }^{4} \\
\text { 4-y OS by d78 MRD 74-77\% } \\
\text { vs. } 31-39 \%(p \leq 0.01)^{4} \\
\text { 4-y RFS by d78 MRD 71-72\% } \\
\text { vs. } 26-34 \%(p \leq 0.01)^{4}\end{array}$ \\
\hline $\begin{array}{l}\text { MDACC } \\
\text { (aBFM/HyperCVAD) } \\
*[36]\end{array}$ & $22(13-39)$ & $93 / 199(47)$ & MFC & $<0.01 \% \mathrm{~d} 29 / \mathrm{d} 84$ & $58(62)$ & $\begin{array}{c}5-y \text { OS by d } 29 \text { MRD 75\% vs. } \\
40 \%(p=0.004) \\
5-y \text { OS by d } 84 \text { MRD 75\% vs. } \\
22 \%(p=0.0004)\end{array}$ \\
\hline $\begin{array}{c}\text { CALGB 10,403 } \\
\text { [37] }\end{array}$ & $24(17-39)$ & $80 / 237(34)$ & Mol & Negative at EOI & $35(44)$ & $\begin{array}{l}3-y \text { RFS } 85 \% \text { vs. } 54 \% \\
\quad(p=0.0006)\end{array}$ \\
\hline \multicolumn{7}{|c|}{ AYA and adults (maximum age $>40$ years) } \\
\hline $\begin{array}{c}\text { NOPHO } 2008 \\
{[14]}\end{array}$ & $26(18-45)$ & $\mathrm{NR} / 218$ & Mol & $<0.1 \%$ d29/d79 & $(56-64)^{5}$ & NR \\
\hline $\begin{array}{c}\text { GRAALL } \\
\text { 2003-2005 [26] }\end{array}$ & $31(15-59)$ & $423 / 860(49)$ & Mol & $\begin{array}{c}\text { Negative } /<0.01 \% \\
\text { w6 }\end{array}$ & $265(63)$ & $\begin{array}{c}5-y \text { CIR } 23-31 \% \text { vs. } 60 \% \\
(p \leq 0.01)\end{array}$ \\
\hline $\begin{array}{c}\text { GMALL 07/03 } \\
\text { [74] }\end{array}$ & $34(16-65)$ & $1057 / 1857$ (57) & Mol & Negative w16 & $625(59)$ & $\begin{array}{l}5-\mathrm{y} \text { OS } 83 \% \text { vs. } 43-68 \% \\
(p<0.0001)^{6}\end{array}$ \\
\hline MDACC [75] & 37 (15-86) & $215 / 394(55)$ & MFC & $\begin{array}{c}<0.01 \% \\
\mathrm{~d} 24 / \mathrm{d} 108\end{array}$ & $147(68) / 194(90)$ & $\begin{array}{l}\text { 3-y OS by d24 MRD 76\% vs. } \\
49-61 \%(p=0.001)^{7} 3-y \text { EFS } \\
\text { by d24 MRD 65\% vs.16-46\% } \\
\qquad(p<0.001)^{7}\end{array}$ \\
\hline $\begin{array}{c}\text { PETHEMA } \\
\text { ALL-HR11 [49] }\end{array}$ & $40(15-60)$ & 286/289 (99) & MFC & $<0.1 \%$ w5-6 & $220(82)$ & $\begin{array}{c}5-y \text { OS } 59 \% \text { vs. } 38 \% \\
(p<0.001)\end{array}$ \\
\hline $\begin{array}{c}\text { NILG } 10 / 07 \\
{[51]}\end{array}$ & $41(18-65)$ & $109 / 140(78)$ & Mol & $\begin{array}{l}<0.01 \% \text { w10- } \\
\text { 16/negative } \\
\text { w22 }\end{array}$ & $68(62)$ & $\begin{array}{l}5-y \text { OS } 78 \% \text { vs. } 34 \% \\
(p<0.0001) \\
5-y \text { RFS 66\% vs. } 29 \% \\
(p<0.0001)\end{array}$ \\
\hline $\begin{array}{l}\text { HOVON-100** } \\
\text { [41] }\end{array}$ & $42(18-70)$ & $168 / 297(56)$ & Mol/MFC & $\begin{array}{c}<0.01 \% \text { after } \\
\text { consolidation } 1\end{array}$ & $126(75)$ & NR \\
\hline
\end{tabular}

Abbreviations: CALGB, Cancer and Leukemia Group B; GIMEMA, Gruppo Italiano Malattie Ematologiche dell'Adulto; GMALL, German Multicenter Study Group for Adult ALL; GRAALL, Group for Research on Adult Acute Lymphoblastic Leukemia; HOVON, HematoOncology Foundation for Adults in the Netherlands; MDACC, M.D. Anderson Cancer Center; NILG, Northern Italy Leukemia Study Group; NOPHO, Nordic Society of Pediatric Hematology and Oncology; PETHEMA, Programa Español de Tratamientos en Hematología; RALL, Russian ALL Study Group; MRC-UKALL, Medical Research Council-United Kingdom ALL Study Group; EFS, event-free survival; OS, overall survival; RFS, relapse-free survival; CIR, cumulative incidence of relapse; NR, not reported (or not available); ${ }^{1} \mathrm{Mol}$, molecular assays; MFC, multiparametric flow cytometry; ${ }^{2} \mathrm{~d}$, day; w, week; EOC, end of consolidation; EOI, end of induction; ${ }^{3}$ observed ranges in MRD positive $(>0.01 \% \mathrm{~d} 29)$ or indeterminate $\left(<0.01 \%\right.$ at EOC); ${ }^{4}$ observed ranges according to MRD timepoint by MFC or Mol method; ${ }^{5} \mathrm{~d} 29$ MRD response rates according to ALL subset (BCP ALL $\left.<100 \mathrm{WBC}, \mathrm{B}-\mathrm{ALL}>100 \mathrm{WBC}, \mathrm{T}-\mathrm{ALL}\right){ }^{6}{ }^{\circ}$ observed range $>$ vs. $\leq 10^{-4}$; 7 observed ranges according to d108 MRD status; * cumulative MRD-based results from both treatment regimens; ** update on all study patients (personal communication by Dr. A.J. Rjineveld, Rotterdam, The Netherlands). 


\subsection{Terminology of MRD Response for Clinical Purposes}

According to technical terminology, an MRD "negative" status (MRD neg) should be intended as an undetectable/unmeasurable MRD using highly sensitive molecular probes (sensitivity $10^{-4}$ to $10^{-5}$ ) or comparable or only slightly less sensitive MFC techniques. In the clinical setting, however, a broader definition of favorable MRD response has been applied until now, from a molecular MRD $<0.1 \% /<10^{-3}$ evaluated at an early time-point to a combination of different MRD reads at different time-points, namely $<0.1-0.01 \% /<$ $10^{-3 /-4}$ early on to $<0.01 \% /<10^{-4}$ and $\mathrm{MRD}_{\text {neg }}$ afterwards. Consequently, uniform MRD terminology for clinical use is presently lacking for adult/AYA ALL trials, although suggestions were provided by expert panels for an MRD $\geq 0.01 \% / \geq 10^{-4}$ at about 12 treatment weeks (i.e., following at least three intensive chemotherapy courses) to represent true high MRD associated with high risk of recurrence $\left(M_{R} D_{\text {pos }}\right)$. Moreover, within the $M R D_{\text {pos }}$ group, increasing MRD levels from $10^{-4}$ to $10^{-1}$ are predictive of an increasingly worse survival [76]. On the contrary, an MRD $<0.01 \% /<10^{-4}$ has been consistently associated with the best clinical outcome independently of treatment type and ALL subset, with minor prognostic differences among $\mathrm{MRD}_{\text {neg }}$ and $\mathrm{MRD}<0.01 \% / 10^{-4}$ patient groups. The $0.01 \% / 10^{-4}$ threshold may therefore be considered the current benchmark for operational definitions in clinical trials, while the distinction of a $\mathrm{MRD}_{\text {neg }}$ status should be maintained to identify the best MRD response and prognostic subset.

\subsection{MRD-Related Outcomes}

As shown in Table 4, whichever the risk stratification, the risk-oriented approach and the MRD study method, the patients who displayed persistent MRD following $\mathrm{CR}$ induction and/or early consolidation chemotherapy fared significantly worse than MRD responders.

However, with few exceptions, MRD was not assessable in about one fourth of CR patients, due to either an insufficient diagnostic and/or follow-up sampling or a failure to generate a molecular probe, while, in this regard, the search for a case-specific LAIP was less troublesome, with success rates $>95 \%$ when it was applied systematically $[35,40,49]$. Performing an adequate ALL cell sampling may become a highly critical issues, because, in some studies, only $50 \%$ or less of the patients underwent MRD analysis [26,37], or this same figure was slightly above $50 \%$ in others [41,44]. These low rates of MRD analysis were more frequent in adult trials and using molecular MRD assays. In the end, in MRD evaluable patients, the average rate of a favorable MRD response after induction-consolidation was about $60-70 \%$, with a trend to higher figures in AYAs. About $35-50 \%$ of all patients achieved a significant MRD reduction early on (collectively at end of induction, EOI) and fared better than others in many reports, mirroring the comparable, much larger experience in childhood ALL.

With regard to MRD-associated outcomes, the data in the table document the substantial prognostic advantage associate with a negative or favorable MRD course as defined in each study. Overall survival probabilities for MRD responders were in the range of $60-70 \%$ and greater, with variations by age group and other, including an early or late MRD response. A pertinent example concerning EOI MRD is illustrated by a sub-analysis of the NILG 10/07 trial [50] in 61 AYA patients aged 18-40 years. While the relapse risk was $24 \%$ at 5 years in the $42 \mathrm{MRD}_{\text {neg }}$ patients $(69 \%)$, those with an EOI/Week $4 \mathrm{MRD}<$ $0.01 \% / 10^{-4}$ confirmed at Week 10 experienced the lowest relapse incidence $(15 \%)$ with an excellent CR duration ( $85 \%$ at 5 years) (Figure 3 ).

Because treatment failure was most commonly caused by an ALL relapse, which in turn is strongly predicted by $M R D_{\text {pos }}$, two main issues deserve to be further elucidated: an "unexpected" recurrence in MRD neg patients and the exact role of an allogeneic HCT salvage (and other therapies) in $\mathrm{MRD}_{\text {pos }}$ patients. 

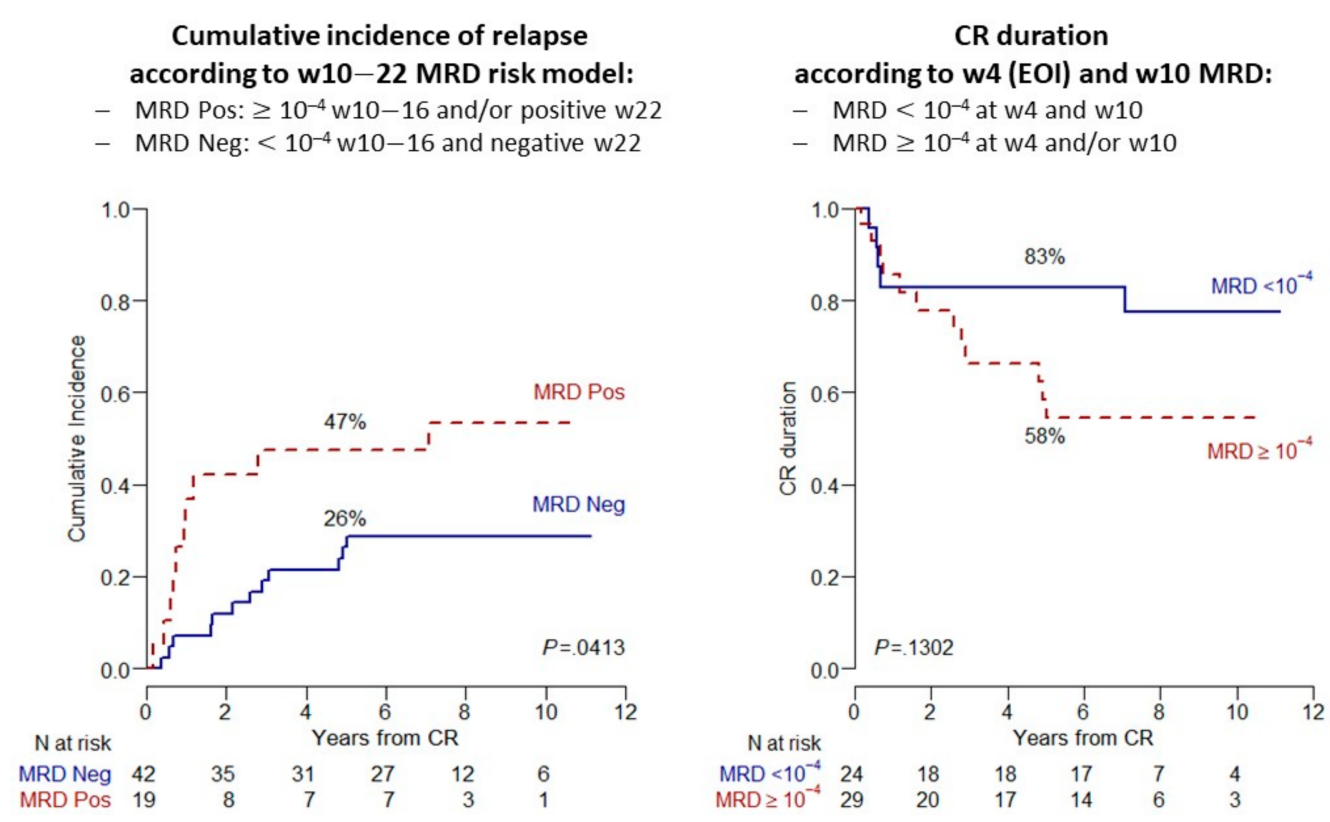

Figure 3. MRD-related incidence of relapse and duration of CR from NILG trial 10/07 in 61 AYA patients aged 10-40 years with Ph-ALL: (Left) cumulative incidence of relapse; and (Right) comparative CR duration in subsets with $\mathrm{MRD}<0.01 \% / 10^{-4}$ at EOI/Week 4 and Week 10 vs. others (non-significant $p$ value due to small patient number).

\subsection{Risk of Relapse in MRD Responders}

Virtually all MRD-based trials and studies reported a fraction of treatment failures in MRD responsive patients, from $10 \%$ to $30-35 \%$, depending on associated risk factors (pa-

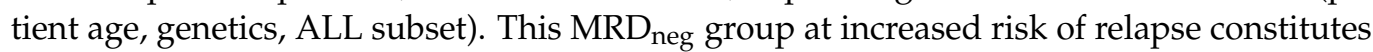
a diagnostic and therapeutic challenge. The more likely explanation for this occurrence could lie in a combination of technical issues and disease biology. Because the sensitivity of the best available techniques currently available for large-scale clinical application does not exceed $0.001 \% / 10^{-5}$, some $\mathrm{MRD}_{\text {neg }}$ patients could still harbor undetectable residual ALL cells able to induce a subsequent relapse. In addition, genetically adverse ALL subsets do worse even if $\mathrm{MRD}_{\text {neg, }}$, as already demonstrated by some studies $[23,26,56,57]$. This suggests that persistence of unmeasurable MRD may be more frequent in some ALL subsets than others, leading to practical considerations for the design of improved risk-oriented strategies, as discussed below.

\subsection{Allogeneic HCT for MRD Positive States}

Thus far, an allogeneic HCT has been the preferred therapeutic option for $\mathrm{MRD}_{\text {pos }}$ patients in risk-oriented trials, to avert the high risk of recurrence expected with the use of chemotherapy only. This indication is shared by the American Society for Transplantation and Cellular Therapy and by all European Study Groups including AYA patients, as stated in an EBMT position paper [54,77]. Another option made available to younger AYA patients in some trials has been further chemotherapy intensification, however with final results below those obtained in $M R D_{\text {neg }}$ patients and/or difficult to interpret due to small patient groups. Currently, the MRD status should to be integrated with ALL genetics and other HR clinical characteristics (such as in Ph-like ALL and ETP-ALL) in the decision-making model driving patients to allogeneic HCT. Consequently, the role of HCT will have to be reassessed combined these new risk definitions, as well as pre-transplantation therapy with novel chemo-immunotherapy combinatory regimens aiming to induce a MRD neg pre-HCT condition (Section 5). 


\subsubsection{Allogeneic HCT Results in MRD pos AYA Ph- ALL}

HCT results obtained in HCT-eligible AYA patients identified through an MRD-based risk stratification and/or other HR criteria are reported in Table 5. Most of these trials reported a significant improvement of EFS/OS with HCT compared to no HCT in these patients, in both AYA and non-AYA groups. Moreover, these trials were not specifically designed to compare allogeneic $\mathrm{HCT}$ to other therapeutic interventions in $M R D_{\text {pos }}$ patients. Several other retrospective studies and meta-analyses, quite heterogeneous as far as HR definition, population age and MRD evaluation, highlighted the advantage of HCT over intensive-pediatric based chemotherapy [8,78-82], even if HCT results were quite variable and to some extent suboptimal because of the occurrence of HCT-related death and posttransplantation relapse in $\mathrm{MRD}_{\text {pos }}$ patients (long-term OS: $45-70 \%$ with vs. $\leq 25 \%$ without).

Table 5. Application and results of allogeneic HCT or other intensification protocols for MRD positive and HR states in AYA/adult Ph- ALL.

\begin{tabular}{|c|c|c|c|}
\hline Trial/Study (Ref.) & $\begin{array}{c}\text { MRD+ and/or HR Patients } \\
\text { Eligible to HCT/HR Protocol } \\
\text { (No.) }\end{array}$ & $\begin{array}{l}\text { Had Allogeneic HCT/HR } \\
\text { Protocol (No.) }\end{array}$ & Outcomes * \\
\hline \multicolumn{4}{|c|}{ AYA only (maximum age 40 years) } \\
\hline PETHEMA ALL08 [35] & $\begin{array}{l}2 \mathrm{MRD}_{\text {pos }} \text { and } 20 \mathrm{HR} \text { to HCT } \\
\text { or HR protocol }\end{array}$ & $5 \mathrm{HCT}$ and $13 \mathrm{HR}$ protocol & $\begin{array}{l}4 \text { HCT survivors ( } 80 \%) \text { and } 7 \\
\text { HR protocol survivors (54\%) }\end{array}$ \\
\hline MRC-UKALL2003 [11] & $\begin{array}{c}109 \mathrm{MRD}_{\text {pos }} \text { to random study } \\
\text { and } 14 \mathrm{HR} \text { to HCT }\end{array}$ & 64 randomized and $14 \mathrm{HCT}$ & 9 HCT survivors $(64 \%)$ \\
\hline MDACC [76] & $17 \mathrm{MRD}_{\text {pos }}$ or $\mathrm{HR}$ to $\mathrm{HCT}$ & $17 \mathrm{HCT}$ & $\begin{array}{c}7 \text { survivors }(41 \%), 5 \text { in } \mathrm{CR} \\
(29 \%)\end{array}$ \\
\hline CALGB 10,403 [37] & $20 \mathrm{HR} /$ other $^{2}$ to HCT & $20 \mathrm{HCT}$ & 8 survivors $(40 \%)$ \\
\hline GIMEMA LAL1308 [40] & $\begin{array}{l}21 \mathrm{MRD}_{\text {pos }} \text { to } \mathrm{HCT} \text { and } \\
9 \mathrm{HR} \text { to HR protocol }\end{array}$ & $15 \mathrm{HCT}$ and $12 \mathrm{HR}$ protocol & $\begin{array}{c}\text { 4-y OS HR } 52.6 \% \text { vs. SR } 73.4 \% \\
(p=0.032) \\
4-y \text { RFS HR 54.2\% vs. SR } \\
66.6 \%(p=0.51)\end{array}$ \\
\hline \multicolumn{4}{|c|}{ AYA and adults (maximum age $>40$ years) } \\
\hline NOPHO 2008 [14] & $\begin{array}{l}35 \mathrm{MRD}_{\text {pos }} \text { to HCT and } 45 \mathrm{HR} \\
\text { to HR protocol }\end{array}$ & NR & 5 -y EFS $61 \%^{3}$ \\
\hline GRAALL 2003-2005 [83] & $105 \mathrm{HR}_{\mathrm{MRD}}$ pos to HCT & $59 \mathrm{HCT}$ & $\begin{array}{c}3-y \text { OS } 65 \% \text { vs. } 40 \%(p=0.001) \\
3-y \text { RFS } 56 \% \text { vs. } \\
22 \%(p=0.002)\end{array}$ \\
\hline GMALL 07/03 [74] & $196 \mathrm{MRD}_{\text {pos }}$ to HCT & $121 \mathrm{HCT}$ & $\begin{array}{l}\text { 5-y OS 53\% vs. } 28 \% \\
(p<0.0001) \\
5-y \text { CRD 56\% vs. } 9 \% \\
(p<0.0001)\end{array}$ \\
\hline PETHEMA ALL-HR11 [49] & $66 \mathrm{MRD}_{\text {pos }}$ and $40 \mathrm{HR}$ to HCT & $62 \mathrm{HCT}$ & $5-\mathrm{y}$ OS $54 \%$ (as treated) \\
\hline NILG 10/07 [51] & $41 \mathrm{MRD}_{\text {pos }}$ to $\mathrm{HCT}$ & $23 \mathrm{HCT}$ & $\begin{array}{c}5-y \text { OS } 35 \% \text { vs. } 14 \%(p=0.02) \\
5-y \text { OS RFS } 43 \% \text { vs. } 12 \% \\
(p=0.09)\end{array}$ \\
\hline
\end{tabular}

Abbreviations: NR, not reported; CRD, CR duration; HR, high-risk; SR, standard risk. * HCT vs. no HCT patients (when available, if not differently indicated); ${ }^{1}$ random study: standard vs. intensified chemotherapy (Vora A et al., Lancet Oncol 2014;15: 809-818); unknown MRD status of HR HCT patients; ${ }^{2}$ at physician's discretion; ${ }^{3}$ with/ without HCT.

\subsubsection{Pre-Transplantation MRD Status}

In $\mathrm{MRD}_{\text {pos }}$ patients, a key time-point for MRD evaluation is just before an allogeneic HCT. MRD positivity at transplantation is the most powerful predictor of relapse and poor outcome, as evidenced by a meta-analysis [84] evaluating 21 retrospective or prospective studies published 1998-2016, all including AYA patients. The pooled results evidenced a 
higher relapse risk (hazard ratio 3.26; $p<0.05$ ) and lower RFS (hazard ratio $2.53 ; p<0.05$ ) in patients with positive pre-transplant MRD in comparison to those with negative MRD. Further studies published 2018-2020 in different transplant settings (related and unrelated donor or haploidentical HCT) and mixed age populations with large percentages of AYA, confirmed the unfavorable prognostic role of pre-HCT MRD pos, with a relapse incidence of $32-73 \%$ vs. $19.7-24 \%$ in pre-HCT MRD neg subsets [85-91]. Thus, achieving an MRD neg status before $\mathrm{HCT}$ in $\mathrm{MRD}_{\text {pos }}$ patients should improve the overall transplantation outcome. The role of new targeted immunotherapy in this setting is discussed in the following section.

\section{New Therapeutic Options for MRD Positive ALL}

\subsection{Immunotherapy for $B C P A L L$}

\subsubsection{Blinatumomab}

Blinatumomab, the first bispecific T-cell engager (BiTE), has been approved for relapsed/refractory (R/R) ALL. In this setting, blinatumomab proved more effective and better tolerated than conventional chemotherapy and able to induce molecular remissions [92]. For its favorable safety profile and mechanism of action, blinatumomab represents the ideal treatment of MRD, and, in fact, it has been extensively tested in this setting both in first or later CR. In two subsequent Phase II clinical studies conducted in $\mathrm{MRD}_{\text {pos }}$ adult ALL patients in hematologic CR but with a high MRD level $\left(\geq 10^{-3}\right)$, a single cycle of blinatumomab induced a major MRD response in about $80 \%$ of the patients $[93,94]$. Based on these results, the United States Food and Drug Administration (FDA) and European Medicines Agency (EMA) both approved blinatumomab as the first drug registered for the treatment of MRD.

Patients treated for MRD positivity in first $C R$ and achieving MRD negativity most frequently are referred to HCT as further consolidation. However, for the time being, there is no evidence that OS is better in patients who did or did not undergo transplantation. On the contrary, the outcome of patients receiving blinatumomab in second or later CR and did not proceed to HCT, proved to be inferior [94].

A real-world effectiveness and safety study of blinatumomab in R/R Ph- B-ALL patients has been recently conducted in Europe. In total, 118 patients were included with a median age of 45 years; $22 \%$ had previous HCT. Within two blinatumomab cycles, $74 \%$ of patients achieved CR or CR with incomplete/partial hematologic recovery: among 44 evaluable patients, $45.5 \%$ had a complete MRD response. The majority $(78 \%)$ of responders proceeded to alloHCT. The estimates for RFS and OS at 24 months were $50 \%$ and $58 \%$, respectively [95].

The impact of blinatumomab on MRD has been recently addressed in high-risk firstrelapse childhood BCP ALL. In this study, patients were randomized to receive one cycle of blinatumomab ( $15 \mu \mathrm{g} / \mathrm{m}^{2} / \mathrm{d}$ for four weeks, continuous intravenous infusion) or chemotherapy as third consolidation before allogeneic HCT. After a median of 22.4 months of follow-up, the incidence of events in the blinatumomab vs. consolidation chemotherapy groups was $31 \%$ vs. $57 \%$ (log-rank $p<0.001)$. MRD remission by PCR was observed in $90 \%$ of patients in the blinatumomab group and in $54 \%$ in the consolidation chemotherapy group [93]. In a second randomized study, the effect of post-reinduction therapy consolidation with blinatumomab vs. chemotherapy was evaluated on DFS in children and AYAs with first relapse of B ALL. The 2-year DFS rate was $54 \%$ for the blinatumomab group vs. $39 \%$ for the chemotherapy group. This difference was considered not statistically significant (one-sided $p=0.03$ ). The 2 -year OS rate was $71 \%$ for the blinatumomab group vs. $58 \%$ for the chemotherapy group. This difference was statistically significant (one-sided $p=0.02$ ). After the first cycle of randomized therapy, the $\mathrm{MRD}_{\text {neg }}$ rate was $75 \%$ for the blinatumomab group vs. $32 \%$ for the chemotherapy group $(p<0.001)$. Finally, for the blinatumomab group, $70 \%$ proceeded to allogeneic HCT, compared with $43 \%$ for the chemotherapy group $(p<0.001)[96]$. 


\subsubsection{Inotuzumab Ozogamicin}

Inotuzumab ozogamicin (InO), a humanized anti-CD22 monoclonal antibody conjugated to the cytotoxic antibiotic calicheamicin has shown strong single agent activity in R/R BCP ALL patients [97]. In this study, patients who received InO versus standard chemotherapy achieved greater remission and $M R D_{\text {neg }}$ rates as well as an improved OS. Compared with $M R D_{\text {pos }}, M_{R} D_{\text {neg }}$ status with $C R$ or $C R$ with incomplete hematologic recovery was associated with significantly improved OS and RFS, respectively. Median OS was 14.1 versus 7.2 months, in the $\mathrm{MRD}_{\text {neg }}$ versus $M R D_{\text {pos }}$ groups [98]. InO is being studied as frontline consolidation drug in AYA Ph - ALL in a North American Phase 3 trial (NCT03150693, C10403 chemotherapy backbone +/ - InO) and for MRD pos IR patients in the new European ALLTogether children and AYA project [55].

\subsection{Chimeric Antigen Receptor-Modified T-Cell Therapy}

In clinical trials for R/R B-ALL, chimeric antigen receptor-modified T-cells (CAR-T) targeting CD19 (Tisagenlecleucel, CTL019) produced CR rates exceeding 80\% to 90\% and became the first CAR T-cell therapy approved by FDA in August 2017. The single-arm, multicenter, global registration trial (ELIANA) conducted across 25 centers demonstrated a $\mathrm{CR}$ rate of $81 \%$ in 75 patients with R/R B-ALL treated with tisagenlecleucel, with undetectable MRD achieved in 100\% of responders. At 12 months, RFS and OS were $59 \%$ and $76 \%$, respectively. Additional clinical trials have been conducted with other CAR-T cell products. While the rate of CR has been largely confirmed [99-104] in adult patients, the duration of response has been significantly less impressive.

A significant clinical benefit was observed particularly in responding patients who also achieved $\mathrm{MRD}_{\text {neg }}$ status. A subsequent allogeneic HCT has also been proposed as an effective strategy to avoid an early relapse after CAR-T cell therapy [105].

Based on these results, it is likely that even for CAR-T cells the greatest benefit could come from an earlier use in the setting of MRD. To validate this hypothesis, in 2019, the COG cooperative group decided to launch the AALL1721/Cassiopeia study, a Phase 2 single-arm trial of tisagenlecleucel in children and young adults in CR1 with high-risk criteria and persistent MRD (by flow cytometry) at the end of chemotherapy. The primary end point of this study is 5-year DFS.

\subsection{Investigational Agents for T-ALL}

T-ALL represents about 20\% of ALL cases and compared to B-precursor ALL offers fewer opportunities for the exploitation of MRD-targeting new agents, partly because they cannot discriminate between normal or regenerating T-cells and residual T-lymphoblasts and could therefore cause an extreme T-cell suppression (fratricide) leading to lethal infections. At present, the clinical experience with immunotherapy and other targeting agents against T-ALL is limited and confined to relapsed/refractory disease, which is in T-ALL an extremely difficult therapeutic setting after the failure of current highly intensive first-line treatments. The only exception to that is nelarabine, which after proving relatively effective at salvage has been evaluated in untreated T-ALL, either frontline or following detection of MRD.

\subsubsection{Nelarabine for $\mathrm{MRD}_{\text {pos }} \mathrm{T}$-ALL}

In a large randomized COG trial [106], the use of nelarabine improved the 4-year RFS vs. the no nelarabine arm ( $88 \%$ vs. $82 \% ; p=0.029)$. In this 4 -arm study conducted in children and AYA 1-30 years, the best outcome was obtained in patients simultaneously randomized to nelarabine and Capizzi-style methotrexate (vs. no nelarabine and/or high-dose methotrexate), with a projected RFS of $91 \%$. While other variably successful nelarabine-based trials have been performed [107] or are near to completion in AYA/adult T-ALL $[17,108]$, a German study was specifically focused on MRD pos T-ALL. In this experience, 6 out of $12 \mathrm{MRD}_{\text {pos }}$ T-ALL patients achieved MRD negativity (50\%) following nelarabine, some were transferred to HCT and only two relapsed [74]. All these data 
prompts further evaluation of nelarabine in MRD $\mathrm{D}_{\text {pos }}$ AYA T-ALL, particularly in adverse subsets such as ETP-ALL, which is associated with a higher risk of MRD persistence $[29,109]$

\subsubsection{Immunotherapy for $M R D_{\text {pos }} \mathrm{T}-\mathrm{ALL}$}

Some new immunotherapeutics could be profitably used against MRD in AYA T-ALL. The most promising agent for large-scale application is the monoclonal antibody daratumumab which is directed against the CD38 antigen, largely represented in T-lymphoblasts. Trials with daratumumab are ongoing, also in combination with chemotherapy, and will be informative about the induction of MRD negativity in clinically responsive patients [108]. In this regard, daratumumab effectively eradicated MRD in some small T-ALL series [110-112]. In a preclinical model, an anti-IL-7R $\alpha$ monoclonal antibody was confirmed effective [113].

By analogy with B-lineage ALL, CAR-T cell therapy is also under investigation in T-ALL, although at a far earlier stage of development [17,108]. These first studies were mainly performed in patients with resistant or relapsing disease and involved anti-CD5, -CD7 and -T-cell receptor $\beta$ CAR-T constructs. A new anti-CD7 CAR-T product generated by CRISPR/Cas9 gene editing technology demonstrated resistant to fratricide and was devoid of any alloreactive/graft-versus-host potential (UCART7) [114]. A comparable CAR-T product from China (TruUCAR GC027) induced four MRD remissions out of five AYA patients aged 19-38 years [115].

\subsection{Other Experimental Approaches}

\subsubsection{Molecular Profiling for Precision Medicine}

A massive amount of data regarding ALL biology and the development of resistance to standard anti-ALL therapy has been generated in recent years [116-121]. These studies paved the way to experimental therapeutic attempts targeting altered molecular pathways [122-125]. Although the clinical experience is thus far limited and involves mainly the late stages of disease, this is a rapidly expanding area with some notable examples that may be considered for the management of $\mathrm{MRD}_{\text {pos }}$ states in AYAs.

1. Most relevant is Ph-like ALL, which is rather frequent in AYA patients and carries a higher risk of MRD persistence. Some of the associated gene abnormalities recognizable in this poor risk entity ( $A B L$-class fusions, CLRF2 deregulation and JAK/STAT and IL7R pathway alterations, among others) are actionable by TK inhibitors, JAK inhibitors (ruxolitinib) and other similar drugs. Trials in children, AYA and adults have been incepted worldwide, sometimes with promising preliminary results [126-129]. The data from these studies may elucidate which of these new drugs or drug combinations with either chemotherapy, immunotherapy and/or other targeting agents could optimize the outcome of the distinct genetically defined Ph-like ALL subsets.

2. Among the BCP ALL subsets to consider for targeted therapy is $t(v ; 11)+$ ALL or ALL carrying KMT2A gene rearrangements, most frequently $t(4 ; 11)+$ ALL. This entity stands out for its clinical aggressiveness. In this subset, the available molecular studies point to a therapeutic use of BCL-2 inhibitors (venetoclax and navitoclax) and DOT-L1 and histone-deacetylase inhibitors; however, the relative rarity of this ALL syndrome precludes an extensive clinical evaluation of these drugs outside large collaborative clinical trials.

3. There are many more candidates for targeted therapy of BCP ALL subsets or ALL in general, as extensively reviewed [122]. Most of these drugs are under investigation in early clinical trials, and it is too early to define exactly their place and/or anticipate their approval for use as standard agents for front-line therapy and/or $\mathrm{MRD}_{\text {pos }}$ conditions. Worthy of mentioning are the proteasome inhibitors, again the BCL-2 inhibitors and the activators of P53-mediated apoptosis, given the frequent dysregulation of these molecular mechanisms. Likewise, the analysis of bone marrow immune cell contexture led to identify a poor risk ALL subset with PD1 + TIM3 + CD4 + bone marrow T-cells $>0.1 \%$ that might be targeted by PD1 checkpoint inhibitors [130]. 
4. Many of the new drugs potentially active in BCP ALL could be exploited in T-ALL as well, namely inhibitors of the antiapoptotic BCL-2 family members and inhibitors of JAK/STAT, PI3K/Akt/mTOR, MAPK and Notch-1, the latter being a typical T-ALL target. While experience with Notch-1 inhibitors has been rather disappointing so far, BCL-2 inhibitors navitoclax and venetoclax induced a CR in six of 16 patients with refractory T-ALL, achieving undetectable MRD in four [129]. ETP ALL may be sensitive to the JAK-2 inhibitor ruxolitinib.

\subsubsection{Drug Sensitivity Profiling for Precision Medicine}

An effective, functional drug screening is now obtainable through ex vivo models that employ extensive drug libraries detecting expected (based on prior molecular screening) or unexpected drug vulnerabilities, together with the evaluation of drug activity in patientderived xenografts (PDX) (reviewed in [122]). These innovative studies may reveal and/or confirm highly promising single-agent or combinatory approaches with new targeting agents in specific ALL entities and/or individual patients. Effective drug combinations were identified for high-risk BCP ALL including Ph-like ALL (BCL-2 and MCL-1 inhibitors; TK inhibitors dasatinib and ponatinib) [131,132], T-ALL and ETP-ALL (ruxolitinib and dexamethasone; dasatinib; and venetoclax and bortezomib) $[133,134]$. This represents an exciting new area for treatment optimization of $\mathrm{MRD}_{\text {pos }}$ states.

\section{Conclusions}

The recent international experience in AYA Ph- ALL confirms that approximately $65 \%$ or more of these patients may achieve cure. This represents an outstanding therapeutic achievement, not very far from the $85-90 \%$ cure rate documented in children and highly encouraging given the different prognostic patterns and the increasing treatment complexity of AYA compared to childhood ALL.

In this field, MRD has emerged as a strong, dominant risk factor, necessary information by which we can modulate treatment intensity up to the level of allogeneic HCT or alternatively choose new treatment modalities (novel immunotherapeutics and new experimental agents) and design innovative risk- and MRD-oriented trials to improve even further the outcome of specific ALL entities.

More than 40 years ago, David Pinkel, a pioneer of ALL therapy, stated that "historically, when therapists have found themselves stymied in improving the prognosis of a disorder, new understanding of its biology has provided the key to further progress" [135]. Today, the study of MRD, which can be regarded as a behavioral marker of ALL biology with function of therapeutic target across all disease and patient subsets, continues to offer new chances of improving the outcome of AYA patients with ALL.

Author Contributions: Conceptualization, R.B. and M.T.; methodology, M.T., O.S., C.P., and R.C.; software, M.T., M.L., and C.P.; formal analysis, C.P.; data curation, M.T., M.L., C.P., F.L., T.I., L.F., G.P., F.C., and P.V.; writing—original draft preparation, R.B., M.T., M.L., C.S., and A.R.; writing-review and editing, M.T., O.S., M.L., C.S., A.R., and R.B.; and supervision, R.B. All authors have read and agreed to the published version of the manuscript.

Funding: This research received no external funding.

Institutional Review Board Statement: Ethical review and approval were waived for this study because it is not applicable to a review article.

Data Availability Statement: No new data were created or analyzed in this study. Data sharing is not applicable to this article.

Conflicts of Interest: The authors declare no conflict of interest. 


\section{References}

1. Surveillance, Epidemiology, and End Results (SEER) Program. SEER Cancer Statistic Review (1975-2017), National Cancer Institute, DCCPS, Surveillance Research Program, Surveillance Systems. Available online: https://Seer.Cancer.Gov/Seerstat/ (accessed on 17 December 2020).

2. Sant, M.; Allemani, C.; Tereanu, C.; De Angelis, R.; Capocaccia, R.; Visser, O.; Marcos-Gragera, R.; Maynadié, M.; Simonetti, A.; Lutz, J.-M.; et al. Incidence of Hematologic Malignancies in Europe by Morphologic Subtype: Results of the HAEMACARE Project. Blood 2010, 116, 3724-3734. [CrossRef]

3. Pui, C.-H.; Evans, W.E. A 50-Year Journey to Cure Childhood Acute Lymphoblastic Leukemia. Semin. Hematol. 2013, 50, 185-196. [CrossRef]

4. Hunger, S.P.; Mullighan, C.G. Acute Lymphoblastic Leukemia in Children. N. Engl. J. Med. 2015, 373, 1541-1552. [CrossRef]

5. Rowe, J.M. Prognostic Factors in Adult Acute Lymphoblastic Leukaemia: Review. Br. J. Haematol. 2010. [CrossRef]

6. Siegel, S.E.; Stock, W.; Johnson, R.H.; Advani, A.; Muffly, L.; Douer, D.; Reed, D.; Lewis, M.; Freyer, D.R.; Shah, B.; et al. Pediatric-Inspired Treatment Regimens for Adolescents and Young Adults With Philadelphia Chromosome-Negative Acute Lymphoblastic Leukemia: A Review. JAMA Oncol. 2018, 4, 725. [CrossRef]

7. Berry, D.A.; Zhou, S.; Higley, H.; Mukundan, L.; Fu, S.; Reaman, G.H.; Wood, B.L.; Kelloff, G.J.; Jessup, J.M.; Radich, J.P. Association of Minimal Residual Disease With Clinical Outcome in Pediatric and Adult Acute Lymphoblastic Leukemia: A Meta-Analysis. JAMA Oncol. 2017, 3, e170580. [CrossRef] [PubMed]

8. Bassan, R.; Intermesoli, T.; Scattolin, A.; Viero, P.; Maino, E.; Sancetta, R.; Carobolante, F.; Gianni, F.; Stefanoni, P.; Tosi, M.; et al. Minimal Residual Disease Assessment and Risk-Based Therapy in Acute Lymphoblastic Leukemia. Clin. Lymphoma Myeloma Leuk. 2017, 17, S2-S9. [CrossRef]

9. Hoelzer, D.; Bassan, R.; Dombret, H.; Fielding, A.; Ribera, J.M.; Buske, C. Acute Lymphoblastic Leukaemia in Adult Patients: ESMO Clinical Practice Guidelines for Diagnosis, Treatment and Follow-Up. Ann. Oncol. 2016, 27, v69-v82. [CrossRef] [PubMed]

10. Short, N.J.; Jabbour, E.; Albitar, M.; de Lima, M.; Gore, L.; Jorgensen, J.; Logan, A.C.; Park, J.; Ravandi, F.; Shah, B.; et al. Recommendations for the Assessment and Management of Measurable Residual Disease in Adults with Acute Lymphoblastic Leukemia: A Consensus of North American Experts. Am. J. Hematol. 2019, 94, 257-265. [CrossRef]

11. Hough, R.; Rowntree, C.; Goulden, N.; Mitchell, C.; Moorman, A.; Wade, R.; Vora, A. Efficacy and Toxicity of a Paediatric Protocol in Teenagers and Young Adults with Philadelphia Chromosome Negative Acute Lymphoblastic Leukaemia: Results from UKALL 2003. Br. J. Haematol. 2016, 172, 439-451. [CrossRef] [PubMed]

12. Larsen, E.C.; Devidas, M.; Chen, S.; Salzer, W.L.; Raetz, E.A.; Loh, M.L.; Mattano, L.A.; Cole, C.; Eicher, A.; Haugan, M.; et al. Dexamethasone and High-Dose Methotrexate Improve Outcome for Children and Young Adults with High-Risk B-Acute Lymphoblastic Leukemia: A Report From Children's Oncology Group Study AALL0232. J. Clin. Oncol. 2016, 34, $2380-2388$. [CrossRef]

13. Winter, S.S.; Dunsmore, K.P.; Devidas, M.; Wood, B.L.; Esiashvili, N.; Chen, Z.; Eisenberg, N.; Briegel, N.; Hayashi, R.J.; GastierFoster, J.M.; et al. Improved Survival for Children and Young Adults with T-Lineage Acute Lymphoblastic Leukemia: Results From the Children's Oncology Group AALL0434 Methotrexate Randomization. J. Clin. Oncol. 2018, 36, 2926-2934. [CrossRef] [PubMed]

14. Toft, N.; Birgens, H.; Abrahamsson, J.; Griškevičius, L.; Hallböök, H.; Heyman, M.; Klausen, T.W.; Jónsson, Ó.; Palk, K.; Pruunsild, K.; et al. Results of NOPHO ALL2008 Treatment for Patients Aged 1-45 Years with Acute Lymphoblastic Leukemia. Leukemia 2018, 32, 606-615. [CrossRef] [PubMed]

15. Bassan, R.; Hoelzer, D. Modern Therapy of Acute Lymphoblastic Leukemia. J. Clin. Oncol. 2011, 29, 532-543. [CrossRef] [PubMed]

16. Carobolante, F.; Chiaretti, S.; Skert, C.; Bassan, R. Practical Guidance for the Management of Acute Lymphoblastic Leukemia in the Adolescent and Young Adult Population. Ther. Adv. Hematol. 2020, 11. [CrossRef] [PubMed]

17. Rank, C.U.; Schmiegelow, K. Optimal Approach to the Treatment of Young Adults with Acute Lymphoblastic Leukemia in 2020. Semin. Hematol. 2020, 57, 102-114. [CrossRef]

18. Roberts, K.G. Genetics and Prognosis of ALL in Children vs. Adults. Hematology 2018, 2018, 137-145. [CrossRef]

19. Moorman, A.V. The Clinical Relevance of Chromosomal and Genomic Abnormalities in B-Cell Precursor Acute Lymphoblastic Leukaemia. Blood Rev. 2012, 26, 123-135. [CrossRef]

20. Chiaretti, S.; Vitale, A.; Cazzaniga, G.; Orlando, S.M.; Silvestri, D.; Fazi, P.; Valsecchi, M.G.; Elia, L.; Testi, A.M.; Mancini, F.; et al. Clinico-Biological Features of 5202 Patients with Acute Lymphoblastic Leukemia Enrolled in the Italian AIEOP and GIMEMA Protocols and Stratified in Age Cohorts. Haematologica 2013, 98, 1702-1710. [CrossRef]

21. Lafage-Pochitaloff, M.; Baranger, L.; Hunault, M.; Cuccuini, W.; Lefebvre, C.; Bidet, A.; Tigaud, I.; Eclache, V.; Delabesse, E.; Bilhou-Nabéra, C.; et al. Impact of Cytogenetic Abnormalities in Adults with Ph-Negative B-Cell Precursor Acute Lymphoblastic Leukemia. Blood 2017, 130, 1832-1844. [CrossRef]

22. Herold, T.; Baldus, C.D.; Gökbuget, N. Ph-like Acute Lymphoblastic Leukemia in Older Adults. N. Engl. J. Med. 2014, $371,2235$. [CrossRef]

23. Hamadeh, L.; Enshaei, A.; Schwab, C.; Alonso, C.N.; Attarbaschi, A.; Barbany, G.; den Boer, M.L.; Boer, J.M.; Braun, M.; Dalla Pozza, L.; et al. Validation of the United Kingdom Copy-Number Alteration Classifier in 3239 Children with B-Cell Precursor ALL. Blood Adv. 2019, 3, 148-157. [CrossRef] 
24. Stanulla, M.; Dagdan, E.; Zaliova, M.; Möricke, A.; Palmi, C.; Cazzaniga, G.; Eckert, C.; te Kronnie, G.; Bourquin, J.-P.; Bornhauser, B.; et al. IKZF1 ${ }^{\text {plus }}$ Defines a New Minimal Residual Disease-Dependent Very-Poor Prognostic Profile in Pediatric B-Cell Precursor Acute Lymphoblastic Leukemia. J. Clin. Oncol. 2018, 36, 1240-1249. [CrossRef]

25. Petit, A.; Trinquand, A.; Chevret, S.; Ballerini, P.; Cayuela, J.-M.; Grardel, N.; Touzart, A.; Brethon, B.; Lapillonne, H.; Schmitt, C.; et al. Oncogenetic Mutations Combined with MRD Improve Outcome Prediction in Pediatric T-Cell Acute Lymphoblastic Leukemia. Blood 2018, 131, 289-300. [CrossRef]

26. Beldjord, K.; Chevret, S.; Asnafi, V.; Huguet, F.; Boulland, M.-L.; Leguay, T.; Thomas, X.; Cayuela, J.-M.; Grardel, N.; Chalandon, Y.; et al. Oncogenetics and Minimal Residual Disease Are Independent Outcome Predictors in Adult Patients with Acute Lymphoblastic Leukemia. Blood 2014, 123, 3739-3749. [CrossRef] [PubMed]

27. Coustan-Smith, E.; Mullighan, C.G.; Onciu, M.; Behm, F.G.; Raimondi, S.C.; Pei, D.; Cheng, C.; Su, X.; Rubnitz, J.E.; Basso, G.; et al. Early T-Cell Precursor Leukaemia: A Subtype of Very High-Risk Acute Lymphoblastic Leukaemia. Lancet Oncol. 2009, 10, 147-156. [CrossRef]

28. Jain, N.; Lamb, A.V.; O’Brien, S.; Ravandi, F.; Konopleva, M.; Jabbour, E.; Zuo, Z.; Jorgensen, J.; Lin, P.; Pierce, S.; et al. Early T-Cell Precursor Acute Lymphoblastic Leukemia/Lymphoma (ETP-ALL/LBL) in Adolescents and Adults: A High-Risk Subtype. Blood 2016, 127, 1863-1869. [CrossRef] [PubMed]

29. Bond, J.; Graux, C.; Lhermitte, L.; Lara, D.; Cluzeau, T.; Leguay, T.; Cieslak, A.; Trinquand, A.; Pastoret, C.; Belhocine, M.; et al. Early Response-Based Therapy Stratification Improves Survival in Adult Early Thymic Precursor Acute Lymphoblastic Leukemia: A Group for Research on Adult Acute Lymphoblastic Leukemia Study. J. Clin. Oncol. 2017, 35, 2683-2691. [CrossRef] [PubMed]

30. Boissel, N.; Auclerc, M.-F.; Lhéritier, V.; Perel, Y.; Thomas, X.; Leblanc, T.; Rousselot, P.; Cayuela, J.-M.; Gabert, J.; Fegueux, N.; et al. Should Adolescents With Acute Lymphoblastic Leukemia Be Treated as Old Children or Young Adults? Comparison of the French FRALLE-93 and LALA-94 Trials. J. Clin. Oncol. 2003, 21, 774-780. [CrossRef]

31. Stock, W.; La, M.; Sanford, B.; Bloomfield, C.D.; Vardiman, J.W.; Gaynon, P.; Larson, R.A.; Nachman, J. What Determines the Outcomes for Adolescents and Young Adults with Acute Lymphoblastic Leukemia Treated on Cooperative Group Protocols? A Comparison of Children's Cancer Group and Cancer and Leukemia Group B Studies. Blood 2008, 112, 1646-1654. [CrossRef]

32. For the Japan Adult Leukemia Study Group (JALSG); Hayakawa, F.; Sakura, T.; Yujiri, T.; Kondo, E.; Fujimaki, K.; Sasaki, O.; Miyatake, J.; Handa, H.; Ueda, Y.; et al. Markedly Improved Outcomes and Acceptable Toxicity in Adolescents and Young Adults with Acute Lymphoblastic Leukemia Following Treatment with a Pediatric Protocol: A Phase II Study by the Japan Adult Leukemia Study Group. Blood Cancer J. 2014, 4, e252. [CrossRef]

33. Nachman, J.B.; La, M.K.; Hunger, S.P.; Heerema, N.A.; Gaynon, P.S.; Hastings, C.; Mattano, L.A.; Sather, H.; Devidas, M.; Freyer, D.R.; et al. Young Adults With Acute Lymphoblastic Leukemia Have an Excellent Outcome With Chemotherapy Alone and Benefit From Intensive Postinduction Treatment: A Report From the Children's Oncology Group. J. Clin. Oncol. 2009, 27, 5189-5194. [CrossRef]

34. Ribera, J.-M.; Oriol, A.; Sanz, M.-A.; Tormo, M.; Fernández-Abellán, P.; del Potro, E.; Abella, E.; Bueno, J.; Parody, R.; Bastida, P.; et al. Comparison of the Results of the Treatment of Adolescents and Young Adults with Standard-Risk Acute Lymphoblastic Leukemia With the Programa Español de Tratamiento En Hematología Pediatric-Based Protocol ALL-96. J. Clin. Oncol. 2008, 26, 1843-1849. [CrossRef] [PubMed]

35. Ribera, J.-M.; Oriol, A.; Morgades, M.; Montesinos, P.; Sarrà, J.; González-Campos, J.; Brunet, S.; Tormo, M.; Fernández-Abellán, P.; Guàrdia, R.; et al. Treatment of High-Risk Philadelphia Chromosome-Negative Acute Lymphoblastic Leukemia in Adolescents and Adults According to Early Cytologic Response and Minimal Residual Disease after Consolidation Assessed by Flow Cytometry: Final Results of the PETHEMA ALL-AR-03 Trial. J. Clin. Oncol. 2014, 32, 1595-1604. [CrossRef] [PubMed]

36. Rytting, M.E.; Jabbour, E.J.; Jorgensen, J.L.; Ravandi, F.; Franklin, A.R.; Kadia, T.M.; Pemmaraju, N.; Daver, N.G.; Ferrajoli, A.; Garcia-Manero, G.; et al. Final Results of a Single Institution Experience with a Pediatric-Based Regimen, the Augmented Berlin-Frankfurt-Münster, in Adolescents and Young Adults with Acute Lymphoblastic Leukemia, and Comparison to the Hyper-CVAD Regimen: Hyper-CVAD versus Pediatric-Based Regimen for AYAs with ALL. Am. J. Hematol. 2016, 91, 819-823. [CrossRef]

37. Stock, W.; Luger, S.M.; Advani, A.S.; Yin, J.; Harvey, R.C.; Mullighan, C.G.; Willman, C.L.; Fulton, N.; Laumann, K.M.; Malnassy, G.; et al. A Pediatric Regimen for Older Adolescents and Young Adults with Acute Lymphoblastic Leukemia: Results of CALGB 10403. Blood 2019, 133, 1548-1559. [CrossRef]

38. Cluzeau, T.; Dhédin, N.; Huguet, F.; Raffoux, E.; Maury, S.; Mannone, L.; Escoffre-Barbe, M.; Le Calloch, R.; Delannoy, A.; Turlure, P.; et al. Dose-Intensity Impacts on Survival of Adolescents and Young Adults with Acute Lymphoblastic Leukemia Trated in Adult Departments by a Pediatric Protocol (FRALLE 2000BT). B. Blood 2012, 120, 3561. [CrossRef]

39. Gökbuget, N.; Beck, J.; Brandt, K.; Brüggemann, M.; Burmeister, T.; Diedrich, H.; Faul, C.; Huettmann, A.; Kondakci, M.; Kraemer, D.M.; et al. Significant Improvement of Outcome in Adolescents and Young Adults (AYAs) Aged 15-35 Years with Acute Lymphoblastic Leukemia with a Pediatric Derived Adult ALL Protocol; Results of 1529 AYAs in 2 Consecutive Trials of the German Multicenter Study Group Dor Adult ALL (GMALL). Blood 2013, 122, 839.

40. Testi, A.M.; Canichella, M.; Vitale, A.; Piciocchi, A.; Guarini, A.; Starza, I.D.; Cavalli, M.; De Propris, M.S.; Messina, M.; Elia, L.; et al. Adolescent and Young Adult Acute Lymphoblastic Leukemia. Final Results of the Phase II Pediatric-like GIMEMA LAL-1308. Trial. Am. J. Hematol 2020. [CrossRef] 
41. Rijneveld, A.W.; van der Holt, B.; de Weerdt, O.; Biemond, B.; van de Loosdrecht, A.; Petersen, E.; Bellido, M.; Schouten, H.; der Velden, W.; Selleslag, D.; et al. Randomized Phase III Hovon-100 Study of Clofarabine Combined with Standard Treatment in Adult Patients with Newly Diagnosed ALL. HemaSphere 2019, 3, 421-422. [CrossRef]

42. DeAngelo, D.J.; Stevenson, K.E.; Dahlberg, S.E.; Silverman, L.B.; Couban, S.; Supko, J.G.; Amrein, P.C.; Ballen, K.K.; Seftel, M.D.; Turner, A.R.; et al. Long-Term Outcome of a Pediatric-Inspired Regimen Used for Adults Aged 18-50 Years with Newly Diagnosed Acute Lymphoblastic Leukemia. Leukemia 2015, 29, 526-534. [CrossRef] [PubMed]

43. DeAngelo, D.J.; Stevenson, K.E.; Neuberg, D.S.; Silverman, L.B.; Ballen, K.K.; Asch, J.D.; Abou Mourad, Y.; Paulson, K.; Seftel, M.D.; Avigan, D.; et al. A Multicenter Phase II Study Using a Dose Intensified Pegylated-Asparaginase Pediatric Regimen in Adults with Untreated Acute Lymphoblastic Leukemia: A DFCI ALL Consortium Trial. Blood 2015, 126, 80. [CrossRef]

44. Gökbuget, N.; Baumann, A.; Beck, J.; Brüggemann, M.; Diedrich, H.; Huettmann, A.; Leimer, L.; Zewen, S.; Mohren, M.; Reichle, A.; et al. PEG-Asparaginase Intensification in Adult Acute Lymphoblastic Leukemia (ALL): Significant Improvement of Outcome with Moderate Increase of Liver Toxicity in the German Multicenter Study Group for Adult ALL (GMALL) Study 07/2003. Blood 2010, 116, 494. [CrossRef]

45. Parovichnikova, E.; Troitskaya, V. Non-Intensive but Constant and Exhausting Action on the Leukemic Clone Is a Reasonable and Effective Treatment Approach in Adult Acute Lymphoblastic Leukemia: Results of the Russian Acute Lymphoblastic Leukemia (RALL) Study Group. Blood 2014, 124, 3662. [CrossRef]

46. Huguet, F.; Leguay, T.; Raffoux, E.; Thomas, X.; Beldjord, K.; Delabesse, E.; Chevallier, P.; Buzyn, A.; Delannoy, A.; Chalandon, Y.; et al. Pediatric-Inspired Therapy in Adults with Philadelphia Chromosome-Negative Acute Lymphoblastic Leukemia: The GRAALL-2003 Study. J. Clin. Oncol. 2009, 27, 911-918. [CrossRef] [PubMed]

47. Huguet, F.; Chevret, S.; Leguay, T.; Thomas, X.; Boissel, N.; Escoffre-Barbe, M.; Chevallier, P.; Hunault, M.; Vey, N.; Bonmati, C.; et al. Intensified Therapy of Acute Lymphoblastic Leukemia in Adults: Report of the Randomized GRAALL-2005 Clinical Trial. J. Clin. Oncol. 2018, 36, 2514-2523. [CrossRef]

48. Storring, J.M.; Minden, M.D.; Kao, S.; Gupta, V.; Schuh, A.C.; Schimmer, A.D.; Yee, K.W.L.; Kamel-Reid, S.; Chang, H.; Lipton, J.H.; et al. Treatment of Adults with BCR-ABL Negative Acute Lymphoblastic Leukaemia with a Modified Paediatric Regimen. Br. J. Haematol. 2009, 146, 76-85. [CrossRef]

49. Ribera, J.-M.; Morgades, M.; Ciudad, J.; Montesinos, P.; Esteve, J.; Genesca, E.; Barba, P.; Ribera, J.; García Cadenas, I.; Moreno, M.J.; et al. Chemotherapy or Allogeneic Transplantation in High-Risk Philadelphia Chromosome-Negative Adult Lymphoblastic Leukemia. Blood 2020. [CrossRef]

50. Sakura, T.; Hayakawa, F.; Sugiura, I.; Murayama, T.; Imai, K.; Usui, N.; Fujisawa, S.; Yamauchi, T.; Yujiri, T.; Kakihana, K.; et al. High-Dose Methotrexate Therapy Significantly Improved Survival of Adult Acute Lymphoblastic Leukemia: A Phase III Study by JALSG. Leukemia 2018, 32, 626-632. [CrossRef]

51. Bassan, R.; Pavoni, C.; Intermesoli, T.; Spinelli, O.; Tosi, M.; Audisio, E.; Marmont, F.; Cattaneo, C.; Borlenghi, E.; Cortelazzo, S.; et al. Updated Risk-Oriented Strategy for Acute Lymphoblastic Leukemia in Adult Patients 18-65 Years: NILG ALL 10/07. Blood Cancer J. 2020, 10, 119. [CrossRef]

52. Stock, W.; Douer, D.; DeAngelo, D.J.; Arellano, M.; Advani, A.; Damon, L.; Kovacsovics, T.; Litzow, M.; Rytting, M.; Borthakur, G.; et al. Prevention and Management of Asparaginase/Pegasparaginase-Associated Toxicities in Adults and Older Adolescents: Recommendations of an Expert Panel. Leuk. Lymphoma 2011, 52, 2237-2253. [CrossRef]

53. Burke, P.W.; Hoelzer, D.; Park, J.H.; Schmiegelow, K.; Douer, D. Managing Toxicities with Asparaginase-Based Therapies in Adult ALL: Summary of an ESMO Open-Cancer Horizons Roundtable Discussion. ESMO Open 2020, 5, e000858. [CrossRef] [PubMed]

54. Giebel, S.; Marks, D.I.; Boissel, N.; Baron, F.; Chiaretti, S.; Ciceri, F.; Cornelissen, J.J.; Doubek, M.; Esteve, J.; Fielding, A.; et al. Hematopoietic Stem Cell Transplantation for Adults with Philadelphia Chromosome-Negative Acute Lymphoblastic Leukemia in First Remission: A Position Statement of the European Working Group for Adult Acute Lymphoblastic Leukemia (EWALL) and the Acute Leukemia Working Party of the European Society for Blood and Marrow Transplantation (EBMT). Bone Marrow Transplant. 2019, 54, 798-809. [CrossRef] [PubMed]

55. A Treatment Study Protocol of the ALLTogether Consortium for Children and Young Adults (1-45 Years of Age) With Newly Diagnosed Acute Lymphoblastic Leukaemia (ALL): A Pilot Study, ClinicalTrials.gov Identifier: NCT03911128.

56. O'Connor, D.; Enshaei, A.; Bartram, J.; Hancock, J.; Harrison, C.J.; Hough, R.; Samarasinghe, S.; Schwab, C.; Vora, A.; Wade, R.; et al. Genotype-Specific Minimal Residual Disease Interpretation Improves Stratification in Pediatric Acute Lymphoblastic Leukemia. J. Clin. Oncol. 2018, 36, 34-43. [CrossRef] [PubMed]

57. Moorman, A.; Kirkwood, A.; Enshaei, A.; Clifton-Hadley, L.; Lawrie, E.; Marks, D.I.; McMillan, A.; Menne, T.; Patrick, P.; Wrench, B.; et al. Clinical Efficacy of a Novel Validated Prognostic Index for Trial Design in Adult Acute Lymphoblastic Leukemia. HemaSphere 2019, 3, 748. [CrossRef]

58. Mignon, L.; DelRocco, N.; Borowitz, M.J.; Rabin, K.R.; Zweidler-Mckay, P.A.; Maloney, K.; Mattano, L.A.; Larsen, E.C.; Angiolillo, A.; Schore, R.; et al. Enhanced Risk Stratification of 21,178 Children, Adolescents, and Young Adults with Acute Lymphoblastic Leukemia (ALL) Incorporating White Blood Count (WBC), Age, and Minimal Residual Disease (MRD) at Day 8 and 29 As Continuous Variables: A Children's Oncology Group (COG) Report. Blood 2020, 136 (Suppl. S1), 39-40.

59. Van Dongen, J.J.M.; Lhermitte, L.; Böttcher, S.; Almeida, J.; van der Velden, V.H.J.; Flores-Montero, J.; Rawstron, A.; Asnafi, V.; Lécrevisse, Q.; Lucio, P.; et al. EuroFlow Antibody Panels for Standardized N-Dimensional Flow Cytometric Immunophenotyping of Normal, Reactive and Malignant Leukocytes. Leukemia 2012, 26, 1908-1975. [CrossRef] [PubMed] 
60. Theunissen, P.; Mejstrikova, E.; Sedek, L.; van der Sluijs-Gelling, A.J.; Gaipa, G.; Bartels, M.; Sobral da Costa, E.; Kotrová, M.; Novakova, M.; Sonneveld, E.; et al. Standardized Flow Cytometry for Highly Sensitive MRD Measurements in B-Cell Acute Lymphoblastic Leukemia. Blood 2017, 129, 347-357. [CrossRef]

61. Van Dongen, J.; Macintyre, E.; Gabert, J.; Delabesse, E.; Rossi, V.; Saglio, G.; Gottardi, E.; Rambaldi, A.; Dotti, G.; Griesinger, F.; et al. Standardized RT-PCR Analysis of Fusion Gene Transcripts from Chromosome Aberrations in Acute Leukemia for Detection of Minimal Residual Disease: Report of the BIOMED-1 Concerted Action: Investigation of Minimal Residual Disease in Acute Leukemia. Leukemia 1999, 13, 1901-1928. [CrossRef]

62. Gabert, J.; Beillard, E.; van der Velden, V.H.J.; Bi, W.; Grimwade, D.; Pallisgaard, N.; Barbany, G.; Cazzaniga, G.; Cayuela, J.M.; Cavé, H.; et al. Standardization and Quality Control Studies of ‘Real-Time' Quantitative Reverse Transcriptase Polymerase Chain Reaction of Fusion Gene Transcripts for Residual Disease Detection in Leukemia-A Europe Against Cancer Program. Leukemia 2003, 17, 2318-2357. [CrossRef]

63. Langerak, A.W.; Groenen, P.J.T.A.; Brüggemann, M.; Beldjord, K.; Bellan, C.; Bonello, L.; Boone, E.; Carter, G.I.; Catherwood, M.; Davi, F.; et al. EuroClonality/BIOMED-2 Guidelines for Interpretation and Reporting of Ig/TCR Clonality Testing in Suspected Lymphoproliferations. Leukemia 2012, 26, 2159-2171. [CrossRef]

64. Van der Velden, V.H.J.; Cazzaniga, G.; Schrauder, A.; Hancock, J.; Bader, P.; Panzer-Grumayer, E.R.; Flohr, T.; Sutton, R.; Cave, H.; Madsen, H.O.; et al. Analysis of Minimal Residual Disease by Ig/TCR Gene Rearrangements: Guidelines for Interpretation of Real-Time Quantitative PCR Data. Leukemia 2007, 21, 604-611. [CrossRef]

65. Knecht, H.; Reigl, T.; Kotrová, M.; Appelt, F.; Stewart, P.; Bystry, V.; Krejci, A.; Grioni, A.; Pal, K.; Stranska, K.; et al. Quality Control and Quantification in IG/TR next-Generation Sequencing Marker Identification: Protocols and Bioinformatic Functionalities by EuroClonality-NGS. Leukemia 2019, 33, 2254-2265. [CrossRef]

66. Scheijen, B.; Meijers, R.W.J.; Rijntjes, J.; van der Klift, M.Y.; Möbs, M.; Steinhilber, J.; Reigl, T.; van den Brand, M.; Kotrová, M.; Ritter, J.-M.; et al. Next-Generation Sequencing of Immunoglobulin Gene Rearrangements for Clonality Assessment: A Technical Feasibility Study by EuroClonality-NGS. Leukemia 2019, 33, 2227-2240. [CrossRef] [PubMed]

67. Brüggemann, M.; Kotrová, M.; Knecht, H.; Bartram, J.; Boudjogrha, M.; Bystry, V.; Fazio, G.; Froňková, E.; Giraud, M.; Grioni, A.; et al. Standardized Next-Generation Sequencing of Immunoglobulin and T-Cell Receptor Gene Recombinations for MRD Marker Identification in Acute Lymphoblastic Leukaemia; a EuroClonality-NGS Validation Study. Leukemia 2019, 33, $2241-2253$. [CrossRef]

68. Wren, D.; Walker, B.A.; Brüggemann, M.; Catherwood, M.A.; Pott, C.; Stamatopoulos, K.; Langerak, A.W.; Gonzalez, D. Comprehensive Translocation and Clonality Detection in Lymphoproliferative Disorders by Next-Generation Sequencing. Haematologica 2017, 102, e57-e60. [CrossRef] [PubMed]

69. Cavagna, R.; Guinea Montalvo, M.L.; Tosi, M.; Paris, M.; Pavoni, C.; Intermesoli, T.; Bassan, R.; Mosca, A.; Rambaldi, A.; Spinelli, O. Capture-Based Next-Generation Sequencing Improves the Identification of Immunoglobulin/T-Cell Receptor Clonal Markers and Gene Mutations in Adult Acute Lymphoblastic Leukemia Patients Lacking Molecular Probes. Cancers 2020, $12,1505$. [CrossRef] [PubMed]

70. Bystry, V.; Reigl, T.; Krejci, A.; Demko, M.; Hanakova, B.; Grioni, A.; Knecht, H.; Schlitt, M.; Dreger, P.; Sellner, L.; et al. ARResT/Interrogate: An Interactive Immunoprofiler for IG/TR NGS Data. Bioinformatics 2016, btw634. [CrossRef] [PubMed]

71. Duez, M.; Giraud, M.; Herbert, R.; Rocher, T.; Salson, M.; Thonier, F. Vidjil: A Web Platform for Analysis of High-Throughput Repertoire Sequencing. PLoS ONE 2016, 11, e0166126. [CrossRef]

72. Faham, M.; Zheng, J.; Moorhead, M.; Carlton, V.E.H.; Stow, P.; Coustan-Smith, E.; Pui, C.-H.; Campana, D. Deep-Sequencing Approach for Minimal Residual Disease Detection in Acute Lymphoblastic Leukemia. Blood 2012, 120, 8.

73. Della Starza, I.; De Novi, L.A.; Santoro, A.; Salemi, D.; Tam, W.; Cavalli, M.; Menale, L.; Soscia, R.; Apicella, V.; Ilari, C.; et al. Digital Droplet PCR and Next-Generation Sequencing Refine Minimal Residual Disease Monitoring in Acute Lymphoblastic Leukemia. Leuk. Lymphoma 2019, 60, 2838-2840. [CrossRef]

74. Gökbuget, N.; Brüggemann, M.; Beck, J.; Faul, C.; Koenecke, C.; Horst, H.-A.; Kondakci, M.; Kraemer, D.M.; Lutz, C.; Spriewald, B.; et al. Evaluation of Minimal Residual Disease (MRD) and MRD-Based Treatment Decisions in Ph/BCR-ABL Negative Adult Acute Lymphoblastic Leukemia (ALL): Experience from the German Multicenter Study Group for Adult ALL (GMALL). Blood 2017, 130, 139.

75. Yilmaz, M.; Kantarjian, H.; Wang, X.; Khoury, J.D.; Ravandi, F.; Jorgensen, J.; Short, N.J.; Loghavi, S.; Cortes, J.; Garcia-Manero, G.; et al. The Early Achievement of Measurable Residual Disease Negativity in the Treatment of Adults with Philadelphia-negative B-cell Acute Lymphoblastic Leukemia Is a Strong Predictor for Survival. Am. J. Hematol. 2020, 95, 144-150. [CrossRef] [PubMed]

76. Gökbuget, N.; Dombret, H.; Giebel, S.; Bruggemann, M.; Doubek, M.; Foà, R.; Hoelzer, D.; Kim, C.; Martinelli, G.; Parovichnikova, E.; et al. Minimal Residual Disease Level Predicts Outcome in Adults with Ph-Negative B-Precursor Acute Lymphoblastic Leukemia. Hematology 2019, 24, 337-348. [CrossRef] [PubMed]

77. DeFilipp, Z.; Advani, A.S.; Bachanova, V.; Cassaday, R.D.; Deangelo, D.J.; Kebriaei, P.; Rowe, J.M.; Seftel, M.D.; Stock, W.; Tallman, M.S.; et al. Hematopoietic Cell Transplantation in the Treatment of Adult Acute Lymphoblastic Leukemia: Updated 2019 Evidence-Based Review from the American Society for Transplantation and Cellular Therapy. Biol. Blood Marrow Transplant. 2019, 25, 2113-2123. [CrossRef]

78. Bassan, R.; Spinelli, O. Minimal Residual Disease Monitoring in Adult ALL to Determine Therapy. Curr. Hematol. Malig. Rep. 2015, 10, 86-95. [CrossRef] 
79. Seftel, M.D.; Neuberg, D.; Zhang, M.-J.; Wang, H.-L.; Ballen, K.K.; Bergeron, J.; Couban, S.; Freytes, C.O.; Hamadani, M.; Kharfan-Dabaja, M.A.; et al. Pediatric-Inspired Therapy Compared to Allografting for Philadelphia Chromosome-Negative Adult ALL in First Complete Remission: Chemotherapy versus Allogeneic HCT in ALL. Am. J. Hematol. 2016, 91, 322-329. [CrossRef]

80. Hangai, M.; Urayama, K.Y.; Tanaka, J.; Kato, K.; Nishiwaki, S.; Koh, K.; Noguchi, M.; Kato, K.; Yoshida, N.; Sato, M.; et al. Allogeneic Stem Cell Transplantation for Acute Lymphoblastic Leukemia in Adolescents and Young Adults. Biol. Blood Marrow Transplant. 2019, 25, 1597-1602. [CrossRef] [PubMed]

81. Wood, W.A.; Lee, S.J.; Brazauskas, R.; Wang, Z.; Aljurf, M.D.; Ballen, K.K.; Buchbinder, D.K.; Dehn, J.; Freytes, C.O.; Lazarus, H.M.; et al. Survival Improvements in Adolescents and Young Adults after Myeloablative Allogeneic Transplantation for Acute Lymphoblastic Leukemia. Biol. Blood Marrow Transplant. 2014, 20, 829-836. [CrossRef] [PubMed]

82. Muffly, L.; Li, Q.; Alvarez, E.; Kahn, J.; Winestone, L.; Cress, R.; Penn, D.C.; Keegan, T.H.M. Hematopoietic Cell Transplantation in Young Adult Acute Lymphoblastic Leukemia: A United States Population-Level Analysis. J. Adolesc. Young Adult Oncol. 2019, 8 , 254-261. [CrossRef]

83. Dhédin, N.; Huynh, A.; Maury, S.; Tabrizi, R.; Beldjord, K.; Asnafi, V.; Thomas, X.; Chevallier, P.; Nguyen, S.; Coiteux, V.; et al. Role of Allogeneic Stem Cell Transplantation in Adult Patients with Ph-Negative Acute Lymphoblastic Leukemia. Blood 2015, 125, 2486-2496. [CrossRef] [PubMed]

84. Shen, Z.; Gu, X.; Mao, W.; Yin, L.; Yang, L.; Zhang, Z.; Liu, K.; Wang, L.; Huang, Y. Influence of Pre-Transplant Minimal Residual Disease on Prognosis after Allo-SCT for Patients with Acute Lymphoblastic Leukemia: Systematic Review and Meta-Analysis. BMC Cancer 2018, 18, 755. [CrossRef]

85. Lovisa, F.; Zecca, M.; Rossi, B.; Campeggio, M.; Magrin, E.; Giarin, E.; Buldini, B.; Songia, S.; Cazzaniga, G.; Mina, T.; et al. Preand Post-Transplant Minimal Residual Disease Predicts Relapse Occurrence in Children with Acute Lymphoblastic Leukaemia. Br. J. Haematol. 2018, 180, 680-693. [CrossRef]

86. Pavlı̊, J.; Labopin, M.; Niittyvuopio, R.; Socié, G.; Yakoub-Agha, I.; Wu, D.; Remenyi, P.; Passweg, J.; Beelen, D.W.; Aljurf, M.; et al. Measurable Residual Disease at Myeloablative Allogeneic Transplantation in Adults with Acute Lymphoblastic Leukemia: A Retrospective Registry Study on 2780 Patients from the Acute Leukemia Working Party of the EBMT. J. Hematol. Oncol.J Hematol. Oncol. 2019, 12, 108. [CrossRef]

87. Xu, M.; Liu, H.; Liu, Y.; Ma, X.; Qiu, H.; Fu, C.; Tang, X.; Han, Y.; Chen, S.; Wu, D.; et al. Gene Mutations and Pretransplant Minimal Residual Disease Predict Risk of Relapse in Adult Patients after Allogeneic Hematopoietic Stem-Cell Transplantation for T Cell Acute Lymphoblastic Leukemia. Leuk. Lymphoma 2019, 60, 2744-2753. [CrossRef] [PubMed]

88. Bader, P.; Salzmann-Manrique, E.; Balduzzi, A.; Dalle, J.-H.; Woolfrey, A.E.; Bar, M.; Verneris, M.R.; Borowitz, M.J.; Shah, N.N.; Gossai, N.; et al. More Precisely Defining Risk Peri-HCT in Pediatric ALL: Pre- vs. Post-MRD Measures, Serial Positivity, and Risk Modeling. Blood Adv. 2019, 3, 3393-3405. [CrossRef]

89. Zhao, X.; Liu, Y.; Xu, L.; Wang, Y.; Zhang, X.; Chen, H.; Chen, Y.; Han, W.; Sun, Y.; Yan, C.; et al. Minimal Residual Disease Status Determined by Multiparametric Flow Cytometry Pretransplantation Predicts the Outcome of Patients with ALL Receiving Unmanipulated Haploidentical Allografts. Am. J. Hematol. 2019, 94, 512-521. [CrossRef]

90. Wang, X.; Fan, Q.; Xu, L.; Wang, Y.; Zhang, X.; Chen, H.; Chen, Y.; Wang, F.; Han, W.; Sun, Y.; et al. The Quantification of Minimal Residual Disease Pre- and Post-Unmanipulated Haploidentical Allograft by Multiparameter Flow Cytometry in Pediatric Acute Lymphoblastic Leukemia. Cytom. B Clin. Cytom. 2020, 98, 75-87. [CrossRef] [PubMed]

91. Kaito, S.; Najima, Y.; Harada, K.; Fukuda, T.; Noguchi, Y.; Ikegame, K.; Tanaka, M.; Ozawa, Y.; Yoshida, S.; Sawa, M.; et al. Allogeneic Hematopoietic Stem Cell Transplantation for Adult Patients with B-Cell Acute Lymphoblastic Leukemia Harboring t(1;19)(Q23;P13.3); Comparison with Normal Karyotype. Bone Marrow Transplant 2020, 55, 1337-1346. [CrossRef] [PubMed]

92. Kantarjian, H.; Stein, A.; Gökbuget, N.; Fielding, A.K.; Schuh, A.C.; Ribera, J.-M.; Wei, A.; Dombret, H.; Foà, R.; Bassan, R.; et al. Blinatumomab versus Chemotherapy for Advanced Acute Lymphoblastic Leukemia. N. Engl. J. Med. 2017, 376, 836-847. [CrossRef]

93. Topp, M.S.; Gökbuget, N.; Zugmaier, G.; Degenhard, E.; Goebeler, M.-E.; Klinger, M.; Neumann, S.A.; Horst, H.A.; Raff, T.; Viardot, A.; et al. Long-Term Follow-up of Hematologic Relapse-Free Survival in a Phase 2 Study of Blinatumomab in Patients with MRD in B-Lineage ALL. Blood 2012, 120, 5185-5187. [CrossRef]

94. Gökbuget, N.; Dombret, H.; Bonifacio, M.; Reichle, A.; Graux, C.; Faul, C.; Diedrich, H.; Topp, M.S.; Brüggemann, M.; Horst, H.-A.; et al. Blinatumomab for Minimal Residual Disease in Adults with B-Cell Precursor Acute Lymphoblastic Leukemia. Blood 2018, 131, 1522-1531. [CrossRef] [PubMed]

95. Thomas, X.; Rijneveld, A.W.; Fracchiolla, N.; Salek, C.; Spyridonidis, A.; Chiaretti, S.; Alam, N.; Pezzani Grueter, I.; Mohammad, A.; Kormany, W.N.; et al. Real-World Effectiveness and Safety of Blinatumumab in Europe: 3-Years Results in Relapsed or Refractory Philadelphia Chromosome-Negative BCP-ALL Patients Including Those with Late First Relapse. In Proceedings of the EBMT 47th Virtual Annual Meeting, Atlanta, GA, USA, 14-17 March 2021.

96. Brown, P.A.; Ji, L.; Xu, X.; Devidas, M.; Hogan, L.E.; Borowitz, M.J.; Raetz, E.A.; Zugmaier, G.; Sharon, E.; Bernhardt, M.B.; et al. Effect of Postreinduction Therapy Consolidation with Blinatumomab vs Chemotherapy on Disease-Free Survival in Children, Adolescents, and Young Adults with First Relapse of B-Cell Acute Lymphoblastic Leukemia: A Randomized Clinical Trial. JAMA 2021, 325, 833-842. [CrossRef] [PubMed] 
97. Kantarjian, H.M.; DeAngelo, D.J.; Stelljes, M.; Martinelli, G.; Liedtke, M.; Stock, W.; Gökbuget, N.; O’Brien, S.; Wang, K.; Wang, T.; et al. Inotuzumab Ozogamicin versus Standard Therapy for Acute Lymphoblastic Leukemia. N. Engl. J. Med. 2016, 375, 740-753. [CrossRef]

98. Jabbour, E.; Gökbuget, N.; Advani, A.; Stelljes, M.; Stock, W.; Liedtke, M.; Martinelli, G.; O’Brien, S.; Wang, T.; Laird, A.D.; et al. Impact of Minimal Residual Disease Status in Patients with Relapsed/Refractory Acute Lymphoblastic Leukemia Treated with Inotuzumab Ozogamicin in the Phase III INO-VATE Trial. Leuk. Res. 2020, 88, 106283. [CrossRef] [PubMed]

99. Lee, D.W.; Kochenderfer, J.N.; Stetler-Stevenson, M.; Cui, Y.K.; Delbrook, C.; Feldman, S.A.; Fry, T.J.; Orentas, R.; Sabatino, M.; Shah, N.N.; et al. T Cells Expressing CD19 Chimeric Antigen Receptors for Acute Lymphoblastic Leukaemia in Children and Young Adults: A Phase 1 Dose-Escalation Trial. Lancet 2015, 385, 517-528. [CrossRef]

100. Curran, K.J.; Margossian, S.P.; Kernan, N.A.; Silverman, L.B.; Williams, D.A.; Shukla, N.; Kobos, R.; Forlenza, C.J.; Steinherz, P.; Prockop, S.; et al. Toxicity and Response after CD19-Specific CAR T-Cell Therapy in Pediatric/Young Adult Relapsed/Refractory B-ALL. Blood 2019, 134, 2361-2368. [CrossRef] [PubMed]

101. Park, J.H.; Rivière, I.; Gonen, M.; Wang, X.; Sénéchal, B.; Curran, K.J.; Sauter, C.; Wang, Y.; Santomasso, B.; Mead, E.; et al. Long-Term Follow-up of CD19 CAR Therapy in Acute Lymphoblastic Leukemia. N. Engl. J. Med. 2018, 378, 449-459. [CrossRef]

102. Hay, K.A.; Gauthier, J.; Hirayama, A.V.; Voutsinas, J.M.; Wu, Q.; Li, D.; Gooley, T.A.; Cherian, S.; Chen, X.; Pender, B.S.; et al. Factors Associated with Durable EFS in Adult B-Cell ALL Patients Achieving MRD-Negative CR after CD19 CAR T-Cell Therapy. Blood 2019, 133, 1652-1663. [CrossRef]

103. Ghorashian, S.; Kramer, A.M.; Onuoha, S.; Wright, G.; Bartram, J.; Richardson, R.; Albon, S.J.; Casanovas-Company, J.; Castro, F.; Popova, B.; et al. Enhanced CAR T Cell Expansion and Prolonged Persistence in Pediatric Patients with ALL Treated with a Low-Affinity CD19 CAR. Nat. Med. 2019, 25, 1408-1414. [CrossRef]

104. Magnani, C.F.; Gaipa, G.; Lussana, F.; Belotti, D.; Gritti, G.; Napolitano, S.; Matera, G.; Cabiati, B.; Buracchi, C.; Borleri, G.; et al. Sleeping Beauty-Engineered CAR T Cells Achieve Antileukemic Activity without Severe Toxicities. J. Clin. Investig. 2020, 130, 6021-6033. [CrossRef]

105. Zhang, X.; Lu, X.; Yang, J.; Zhang, G.; Li, J.; Song, L.; Su, Y.; Shi, Y.; Zhang, M.; He, J.; et al. Efficacy and Safety of Anti-CD19 CAR T-Cell Therapy in 110 Patients with B-Cell Acute Lymphoblastic Leukemia with High-Risk Features. Blood Adv. 2020, 4, 2325-2338. [CrossRef] [PubMed]

106. Dunsmore, K.P.; Winter, S.S.; Devidas, M.; Wood, B.L.; Esiashvili, N.; Chen, Z.; Eisenberg, N.; Briegel, N.; Hayashi, R.J.; GastierFoster, J.M.; et al. Children's Oncology Group AALL0434: A Phase III Randomized Clinical Trial Testing Nelarabine in Newly Diagnosed T-Cell Acute Lymphoblastic Leukemia. J. Clin. Oncol. 2020, 38, 3282-3293. [CrossRef]

107. Abaza, Y.; Kantarjian, H.M.; Faderl, S.; Jabbour, E.; Jain, N.; Thomas, D.; Kadia, T.; Borthakur, G.; Khoury, J.D.; Burger, J.; et al. Hyper-CVAD plus Nelarabine in Newly Diagnosed Adult T-Cell Acute Lymphoblastic Leukemia and T-Lymphoblastic Lymphoma. Am. J. Hematol. 2018, 93, 91-99. [CrossRef] [PubMed]

108. O'Dwyer, K.M. The Challenge to Further Improvements in Survival of Patients with T-ALL: Current Treatments and New Insights from Disease Pathogenesis. Semin. Hematol. 2020, 57, 149-156. [CrossRef] [PubMed]

109. Wood, B.L.; Winter, S.S.; Dunsmore, K.P.; Devidas, M.; Chen, S.; Asselin, B.L.; Esiashvili, N.; Loh, M.L.; Winick, N.J.; Carroll, W.L.; et al. T-Lymphoblastic Leukemia (T-ALL) Shows Excellent Outcome, Lack of Significance of the Early Thymic Precursor (ETP) Immunophenotype, and Validation of the Prognostic Value of End-Induction Minimal Residual Disease (MRD) in Children's Oncology Group (COG) Study AALL0434. Blood 2014, 124, 21.

110. Ofran, Y.; Ringelstein-Harlev, S.; Slouzkey, I.; Zuckerman, T.; Yehudai-Ofir, D.; Henig, I.; Beyar-Katz, O.; Hayun, M.; Frisch, A. Daratumumab for Eradication of Minimal Residual Disease in High-Risk Advanced Relapse of T-Cell/CD19/CD22-Negative Acute Lymphoblastic Leukemia. Leukemia 2020, 34, 293-295. [CrossRef] [PubMed]

111. Vogiatzi, F.; Winterberg, D.; Lenk, L.; Buchmann, S.; Cario, G.; Schrappe, M.; Peipp, M.; Richter-Pechanska, P.; Kulozik, A.E.; Lentes, J.; et al. Daratumumab Eradicates Minimal Residual Disease in a Preclinical Model of Pediatric T-Cell Acute Lymphoblastic Leukemia. Blood 2019, 134, 713-716. [CrossRef]

112. Cerrano, M.; Castella, B.; Lia, G.; Olivi, M.; Faraci, D.G.; Butera, S.; Martella, F.; Scaldaferri, M.; Cattel, F.; Boccadoro, M.; et al. Immunomodulatory and Clinical Effects of Daratumumab in T-cell Acute Lymphoblastic Leukaemia. Br. J. Haematol. $2020,191$. [CrossRef]

113. Hixon, J.A.; Andrews, C.; Kashi, L.; Kohnhorst, C.L.; Senkevitch, E.; Czarra, K.; Barata, J.T.; Li, W.; Schneider, J.P.; Walsh, S.T.R.; et al. New Anti-IL-7R $\alpha$ Monoclonal Antibodies Show Efficacy against T Cell Acute Lymphoblastic Leukemia in Pre-Clinical Models. Leukemia 2020, 34, 35-49. [CrossRef]

114. Cooper, M.L.; Choi, J.; Staser, K.; Ritchey, J.K.; Devenport, J.M.; Eckardt, K.; Rettig, M.P.; Wang, B.; Eissenberg, L.G.; Ghobadi, A.; et al. An "off-the-Shelf" Fratricide-Resistant CAR-T for the Treatment of T Cell Hematologic Malignancies. Leukemia 2018, 32, 1970-1983. [CrossRef] [PubMed]

115. Wang, X.; Li, S.; Gao, L.; Yuan, Z.; Wu, K.; Liu, L.; Luo, L.; Liu, Y.; Zhang, C.; Liu, J.; et al. Abstract CT052: Clinical Safety and Efficacy Study of TruUCAR ${ }^{\mathrm{TM}}$ GC027: The First-in-Human, Universal CAR-T Therapy for Adult Relapsed/Refractory T-Cell Acute Lymphoblastic Leukemia (r/r T-ALL). Cancer Res. 2020, 80, 16.

116. Bongiovanni, D.; Saccomani, V.; Piovan, E. Aberrant Signaling Pathways in T-Cell Acute Lymphoblastic Leukemia. Int. J. Mol. Sci. 2017, 18, 1904. [CrossRef] 
117. García-Peydró, M.; Fuentes, P.; Mosquera, M.; García-León, M.J.; Alcain, J.; Rodríguez, A.; García de Miguel, P.; Menéndez, P.; Weijer, K.; Spits, H.; et al. The NOTCH1/CD44 Axis Drives Pathogenesis in a T Cell Acute Lymphoblastic Leukemia Model. J. Clin. Investig. 2018, 128, 2802-2818. [CrossRef] [PubMed]

118. Li, B.; Yan, J.; Phyu, T.; Fan, S.; Chung, T.-H.; Mustafa, N.; Lin, B.; Wang, L.; Eichhorn, P.J.A.; Goh, B.-C.; et al. MELK Mediates the Stability of EZH2 through Site-Specific Phosphorylation in Extranodal Natural Killer/T-Cell Lymphoma. Blood 2019, 134, 2046-2058. [CrossRef] [PubMed]

119. Gu, Z.; Churchman, M.L.; Roberts, K.G.; Moore, I.; Zhou, X.; Nakitandwe, J.; Hagiwara, K.; Pelletier, S.; Gingras, S.; Berns, H.; et al. PAX5-Driven Subtypes of B-Progenitor Acute Lymphoblastic Leukemia. Nat. Genet. 2019, 51, 296-307. [CrossRef]

120. Autry, R.J.; Paugh, S.W.; Carter, R.; Shi, L.; Liu, J.; Ferguson, D.C.; Lau, C.E.; Bonten, E.J.; Yang, W.; McCorkle, J.R.; et al. Integrative Genomic Analyses Reveal Mechanisms of Glucocorticoid Resistance in Acute Lymphoblastic Leukemia. Nat. Cancer 2020, 1, 329-344. [CrossRef]

121. Waanders, E.; Gu, Z.; Dobson, S.M.; Antić, Ž.; Crawford, J.C.; Ma, X.; Edmonson, M.N.; Payne-Turner, D.; van de Vorst, M.; Jongmans, M.C.J.; et al. Mutational Landscape and Patterns of Clonal Evolution in Relapsed Pediatric Acute Lymphoblastic Leukemia. Blood Cancer Discov. 2020, 1, 96-111. [CrossRef] [PubMed]

122. Bassan, R.; Bourquin, J.-P.; DeAngelo, D.J.; Chiaretti, S. New Approaches to the Management of Adult Acute Lymphoblastic Leukemia. J. Clin. Oncol. 2018, 36, 3504-3519. [CrossRef]

123. Mullighan, C.G. How Advanced Are We in Targeting Novel Subtypes of ALL? Best Pract. Res. Clin. Haematol. 2019, $32,101095$. [CrossRef]

124. Follini, E.; Marchesini, M.; Roti, G. Strategies to Overcome Resistance Mechanisms in T-Cell Acute Lymphoblastic Leukemia. Int. J. Mol. Sci. 2019, 20, 3021. [CrossRef]

125. Pui, C.-H. Precision Medicine in Acute Lymphoblastic Leukemia. Front. Med. 2020, 14, 689-700. [CrossRef]

126. Chiaretti, S.; Messina, M.; Foà, R. BCR/ABL1 -like Acute Lymphoblastic Leukemia: How to Diagnose and Treat?: Open Questions in BCR/ABL1-Like ALL. Cancer 2019, 125, 194-204. [CrossRef]

127. Tanasi, I.; Ba, I.; Sirvent, N.; Braun, T.; Cuccuini, W.; Ballerini, P.; Duployez, N.; Tanguy-Schmidt, A.; Tamburini, J.; Maury, S.; et al. Efficacy of Tyrosine Kinase Inhibitors in Ph-like Acute Lymphoblastic Leukemia Harboring ABL-Class Rearrangements. Blood 2019, 134, 1351-1355. [CrossRef] [PubMed]

128. Harvey, R.C.; Tasian, S.K. Clinical Diagnostics and Treatment Strategies for Philadelphia Chromosome-like Acute Lymphoblastic Leukemia. Blood Adv. 2020, 4, 218-228. [CrossRef] [PubMed]

129. Moorman, A.V.; Schwab, C.; Winterman, E.; Hancock, J.; Castleton, A.; Cummins, M.; Gibson, B.; Goulden, N.; Kearns, P.; James, B.; et al. Adjuvant Tyrosine Kinase Inhibitor Therapy Improves Outcome for Children and Adolescents with Acute Lymphoblastic Leukaemia Who Have an ABL-class Fusion. Br. J. Haematol. 2020, 191, 844-851. [CrossRef]

130. Hohtari, H.; Brück, O.; Blom, S.; Turkki, R.; Sinisalo, M.; Kovanen, P.E.; Kallioniemi, O.; Pellinen, T.; Porkka, K.; Mustjoki, S. Immune Cell Constitution in Bone Marrow Microenvironment Predicts Outcome in Adult ALL. Leukemia 2019, 33, $1570-1582$. [CrossRef] [PubMed]

131. Chiaretti, S.; Messina, M.; Grammatico, S.; Piciocchi, A.; Fedullo, A.L.; Di Giacomo, F.; Peragine, N.; Gianfelici, V.; Lauretti, A.; Bareja, R.; et al. Rapid Identification of BCR/ABL1 -like Acute Lymphoblastic Leukaemia Patients Using a Predictive Statistical Model Based on Quantitative Real Time-Polymerase Chain Reaction: Clinical, Prognostic and Therapeutic Implications. Br. J. Haematol. 2018, 181, 642-652. [CrossRef]

132. Moujalled, D.M.; Hanna, D.T.; Hediyeh-zadeh, S.; Pomilio, G.; Brown, L.; Litalien, V.; Bartolo, R.; Fleming, S.; Chanrion, M.; Banquet, S.; et al. Cotargeting BCL-2 and MCL-1 in High-Risk B-ALL. Blood Adv. 2020, 4, 2762-2767. [CrossRef] [PubMed]

133. Verbeke, D.; Gielen, O.; Jacobs, K.; Boeckx, N.; De Keersmaecker, K.; Maertens, J.; Uyttebroeck, A.; Segers, H.; Cools, J. Ruxolitinib Synergizes With Dexamethasone for the Treatment of T-Cell Acute Lymphoblastic Leukemia. HemaSphere 2019, 3, e310. [CrossRef]

134. La Starza, R.; Cambò, B.; Pierini, A.; Bornhauser, B.; Montanaro, A.; Bourquin, J.-P.; Mecucci, C.; Roti, G. Venetoclax and Bortezomib in Relapsed/Refractory Early T-Cell Precursor Acute Lymphoblastic Leukemia. JCO Precis. Oncol. $2019,1-6$. [CrossRef]

135. Pinkel, D. The Ninth Annual David Karnofsky Lecture. Treatment of Acute Lymphocytic Leukemia. Cancer 1979, $43,1128-1137$. [CrossRef] [PubMed] 